\title{
Lignin Degradation Processes and the Purification of Valuable Products
}

\author{
Stefan Schoenherr, Mehrdad Ebrahimi and \\ Peter Czermak \\ Additional information is available at the end of the chapter
}

http://dx.doi.org/10.5772/intechopen.71210

\begin{abstract}
Lignin is a heterogeneous, phenolic and polydisperse biopolymer which resists degradation due to its aromatic and highly branched structure. Lignin is the most abundant renewable source of aromatic molecules on earth. The valorization of lignin could therefore provide a sustainable alternative to petroleum refineries for the production of valuable aromatic compounds. Even so, paper mills and lignocellulose feedstock biorefineries treat lignin largely as a waste product. In paper mills, $98 \%$ of technical lignin is incinerated for internal energy recovery while only $2 \%$ is used commercially (e.g. for the production of aromatics such as vanillin). The reasons for the underutilization of lignin include its recalcitrance to degradation and the challenge of separating mixtures of numerous degradation products. The successful valorization of lignin in the future thus depends on a broad understanding of biological and technical degradation processes, and the implementation of efficient product purification strategies. This article describes enzymatic, photocatalytic and thermochemical lignin degradation processes and considers purification methods for valuable lignin-derived degradation products. We focus on the potential of membrane-based separation technology, including data from our own recent research.
\end{abstract}

Keywords: lignin valorization, lignin degradation, enzymatic lignin degradation, thermochemical lignin degradation, photocatalytic lignin degradation, enzyme membrane reactor system (EMRS), membrane filtration, ceramic membranes

\section{Introduction}

Lignin, cellulose and hemicellulose are the main constituents of lignocellulosic biomass, with lignin accounting for $\sim 10-40 \%$ by weight [1]. The biological functions of lignin in vascular 
plants are to provide rigidity and to protect the structural polysaccharides cellulose and hemicellulose from enzymatic hydrolysis [2-4]. Lignin is a heterogeneous, crosslinked and highly polydisperse phenolic copolymer of three different monolignols: p-coumaryl alcohol, coniferyl alcohol and sinapyl alcohol $[3,5]$. When integrated into the lignin macromolecule, the building blocks based on these monolignols are the $p$-hydroxyphenyl unit $(\mathrm{H})$, guaiacyl unit (G) and syringyl unit (S) (Figure 1) [6]. The distribution of these monomers varies in different plant species and tissues. Generally, lignin from grasses is a roughly equimolar mixture of $G, S$ and $\mathrm{H}$ units, whereas lignin from hardwood contains approximately equal quantities of $\mathrm{G}$ and $\mathrm{S}$ units but relatively small amounts of the $\mathrm{H}$ unit, and lignin from softwood is mainly composed of G units (up to 90\%) [7]. However, variations within these groups of species have been reported, for example, lignin from silver birch (Betula pendula) and several Eucalyptus species contains $65-80 \% \mathrm{~S}$ units, rather than the roughly equimolar mixture of $\mathrm{G}$ and $\mathrm{S}$ units typical for hardwoods [8, 9].

The natural polymerization of monolignols (lignification) starts with the oxidative formation of phenoxy radicals catalyzed by peroxidases and/or laccases, and is followed by combinatorial

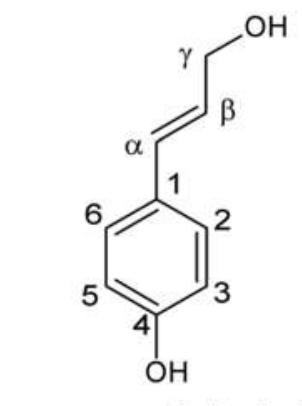

p-coumaryl alcohol

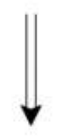<smiles>COc1c(C)cc(C(C)(C)C)cc1C</smiles>

p-hydroxyphenyl $(\mathrm{H})$ unit

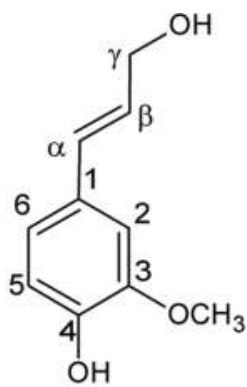

coniferyl alcohol
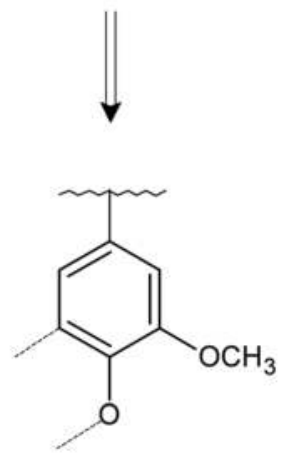

guaiacyl (G) unit<smiles>COc1cc(/C=C/CO)cc(OC)c1O</smiles>

sinapyl alcohol<smiles>C=CCc1cc(OC)c(OC)c(OC)c1</smiles>

syringyl (S) unit

Figure 1. Chemical structure of monolignols and the corresponding building blocks in lignin. 
radical coupling, generating carbon-carbon and carbon-oxygen (ether) bonds [6, 10]. The emerging crosslinked network and aromatic nature of lignin explain its recalcitrance towards degradation [11]. The most frequent linkages formed during lignification are $\beta$-O- 4 bonds, which represent $\sim 50 \%$ of all linkages between monolignol building blocks in hardwood and softwood lignin (Table 1) [3, 12]. The main linkage types in hardwood and softwood lignin are summarized in Table 1 and are represented schematically in Figure 2.

\begin{tabular}{lll}
\hline & & [\%] \\
\cline { 2 - 3 } Linkage type & Hardwood lignin & Softwood lignin \\
\hline$\beta-\mathrm{O}-4$ & $50-65$ & $43-50$ \\
$\beta-5+$ cyclic $\alpha-\mathrm{O}-4$ & $4-6$ & $9-12$ \\
noncyclic $\alpha-\mathrm{O}-4$ & $4-8$ & $6-8$ \\
$4-\mathrm{O}-5$ & $6-7$ & 4 \\
$\beta-\beta$ & $3-7$ & $2-4$ \\
$5-5$ & $4-10$ & $10-25$ \\
$\beta-1$ & $5-7$ & $3-7$ \\
\hline
\end{tabular}

Table 1. Distribution of principal lignin building block linkages in hardwood and softwood (\%), adapted from [13].

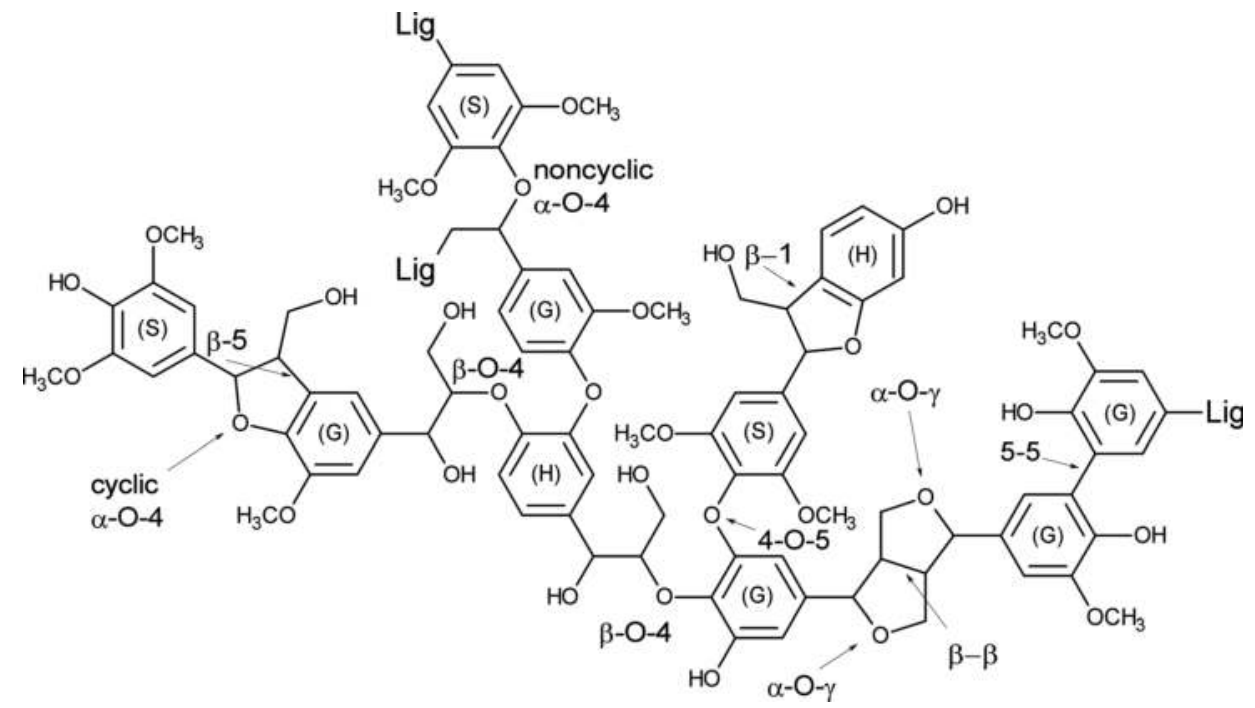

Figure 2. Schematic representation of a hypothetical lignin structure, including principal linkage types and building blocks (H, G and S). 
Lignin is the most abundant renewable source of aromatic molecules and the second largest renewable source of carbon on earth, after cellulose [3, 14]. The estimated total amount of lignin on earth is $\sim 300 \times 10^{9}$ tons, and the annual amount produced by natural lignification is $\sim 20 \times 10^{9}$ tons [15].

There is great scientific and industrial interest in lignin due to the growing threat of climate change and the urgent need to reduce relevant emissions [16-18]. Lignin offers a sustainable alternative to the finite fossil resources currently used to produce aromatic compounds, and it is widely regarded as a waste product and is therefore inexpensive $[19,20]$. One possible area of application for lignin-derived aromatic products is conventional jet fuel, which contains $20 \%$ fossil-derived aromatic compounds that could be replaced with lignin-derived compounds [21]. As well as the presence of valuable aromatic constituents, one of the main reasons for the interest in lignin is its availability, either directly from plants or as a byproduct of industrial conversion processes [22]. The pulp and paper industries, as well as lignocellulose feedstock biorefineries producing liquid fuels such as bioethanol, provide major examples of these processes [23, 24]. Lignin derived from industrial conversion processes is described hereafter as industrial or technical lignin.

Approximately 50 million tons of technical lignin is generated annually by the pulp and paper industries [15]. Depending on the pulping process, different forms of lignin are produced with distinct chemical properties, including kraft lignin, lignosulfonate, organosolv lignin, soda lignin and residual lignin from the bleaching stage (Figure 3) [19]. Even more industrial lignin is expected to be produced in lignocellulose feedstock biorefineries. The United States

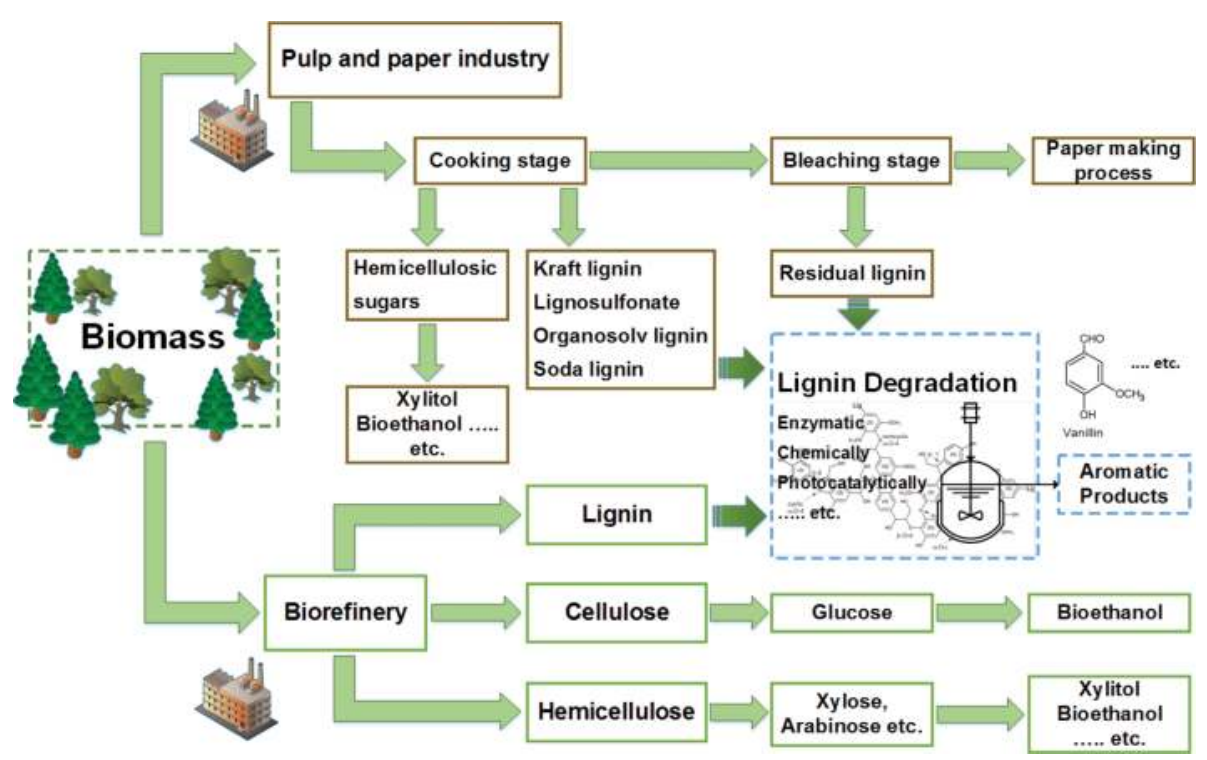

Figure 3. Lignin sources and pathways to generate valuable products from lignocellulosic biomass (highly simplified representation of process steps in the pulp and paper industry). 
Department of Energy has set a goal to replace 30\% of the transportation fuel supply with biofuels by 2030 . This would require $\sim 750$ million tons of biomass and would release $\sim 225$ million tons of lignin in the United States alone [25]. However, process streams containing technical lignin originating from the pulp and paper industries and biorefineries tend to be treated as waste, and are therefore significantly underutilized. More than $98 \%$ of the industrial lignin produced by the pulp and paper industry is incinerated for internal energy recovery while only $2 \%$ is used commercially, mostly for niche products [15, 26, 27]. The contrast between lignin's huge economic potential as a source of value-added aromatic products and its classification as a waste product mainly reflects its recalcitrance to degradation, its heterogeneity and the challenge of isolating valuable molecules from a complex mixture of degradation products.

Lignin biodegradation clearly occurs in nature, otherwise all carbon would eventually become trapped in lignocellulosic biomass [11]. However, it has not yet been possible to replicate these enzymatic processes on an industrial scale. Instead, industrial lignin degradation is currently based on chemical processes. One example is the production of vanillin from lignosulfonates, which involves lignin degradation via alkaline oxidation [27]. The existence of such industrial processes for lignin valorization indicates that large-scale valorization and the full exploitation of technical lignin as a source of aromatic fine chemicals should be possible in the future, thus replacing the current use of unsustainable fossil resources. In addition to improving the efficiency of chemical processes, it should also be possible to scale up enzymatic lignindegradation processes, including those based on an enzyme membrane reactor system (EMRS). This article discusses current research on the topic of industrial lignin degradation and valorization, including enzymatic, thermochemical and photocatalytic lignin-degradation methods. We also consider separation techniques for lignin-containing process streams, focusing on membrane technology.

\section{Lignin degradation processes}

Lignin degradation is often investigated using model lignin compounds rather than real lignin-containing substrates. The basic principles of lignin degradation, such as the reaction kinetics and conversion pathways, are easier to analyze using simple model compounds rather than complex lignin solutions because real substrates are heterogeneous, resulting in multiple overlapping degradation reactions.

\subsection{Enzymatic lignin degradation}

As stated above, one function of lignin in lignocellulosic biomass is to protect cellulose and hemicellulose from enzymatic hydrolysis. Non-lignified cellulose and hemicellulose are accessible for enzymatic hydrolysis, which enables their conversion into monosaccharides. Hydrolases (cellulases and hemicellulases) can produce monosaccharides in large quantities, and the industrial valorization of cellulose and hemicellulose by hydrolytic enzymatic processes is already well established (e.g., cellulosic bioethanol production and xylitol from xylose-rich hemicelluloses) $[1,28,29]$. When these polysaccharides are found in complex 
connection with lignin, as in lignocellulosic biomass, they are strongly resistant to hydrolysis [30]. Given that lignin inhibits the degradation of cellulose and hemicellulose, microbes that utilize these molecules have evolved pathways for lignin decomposition or modification in order to gain access to the polysaccharides, which they use as sources of carbon and energy [4].

\subsubsection{Fungal lignin degradation}

The fungal decomposition of lignocellulose relies on two types of extracellular enzyme systems. First, fungi can deploy hydrolases (cellulases and hemicellulases) for the degradation of structural lignocellulosic polysaccharides (cellulose and hemicellulose). Second, they possess a unique extracellular ligninolytic system that degrades or modifies lignin [31]. The prevalence of these systems differs with the type of fungus. Three types of fungal wood decay can be distinguished: white-rot, brown-rot and soft-rot [32]. Wood decayed by whiterot fungi is pale and often takes on a fibrous texture [33, 34]. Common white-rot fungi include Phanerochaete chrysosporium, Pleurotus ostreatus and Ceriporiopsis subvermispora [35]. Kirk and Farrell [3] claimed-based on literature analysis - that white-rot fungi were the best lignin degraders among all studied microorganisms, achieving degradation more rapidly and more comprehensively, even to the extent of complete mineralization. The fungi invade the lumens of wood cells and secrete enzymes that degrade lignin and the associated polysaccharides [3]. White-rot fungi predominantly degrade deciduous wood (hardwood). In contrast, brown-rot fungi grow primarily on coniferous wood (softwood) and are therefore mainly softwood degraders. Both white-rot and brown-rot fungi show host preferences [35]. Brown-rot fungi are an exception to the typical observation that lignocellulose must be lignified before access to lignocellulosic polysaccharides is granted, and degradation made possible [4]. They do not degrade lignin directly, but rather modify it by partial oxidization and then preferentially degrade the polysaccharides [36, 37]. Wood decomposed by brownrot fungi is therefore characterized by a brown color arising from the residual lignin [33]. In addition to color changes, wood decayed by brown-rot fungi shrinks, breaks into brickshaped pieces and crumbles to a brown powder [38]. Typical examples of brown-rot fungi include Gloeophyllum trabeum, Postia placenta and Fomitopsis palustris [36, 39]. The third group of wood-decaying fungi are the soft-rot fungi [4]. Finally, Findlay and Savory [40] introduced this term for wood decay based on the deterioration of timbers in water-cooling towers. Softrot fungi are responsible for wood decay in water-saturated systems or areas with fluctuating moisture levels. Typical examples include Chaetomium cochliodes, Chaetomium globosum and Ophiostoma coerulescens [41]. They are slower and less aggressive than white-rot and brown-rot fungi, and preferentially utilize polysaccharides, but they can also decompose lignin to a certain degree. Research has focused more on brown-rot and especially white-rot fungi than soft-rot fungi [4].

\subsubsection{Enzymes involved in fungal lignin degradation}

Successful lignin decomposition can only be achieved by the application of multiple enzymes due to the complexity and heterogeneity of lignin and the diverse chemical linkages it contains [19]. 
Therefore, the biodegradation of wood constituents (ligninolysis) is widely understood as a multi-enzymatic process that produces many intermediates [30]. However, fungal ligninolysis does not involve one specific set of dedicated enzymes [42]. Instead, the composition of the multienzymatic mixture depends on the type of fungus [11].

Enzymes responsible for lignin degradation are known as ligninases [43]. The most common fungal ligninases are copper-containing laccases and heme peroxidases, the latter defined further as lignin peroxidases $(\mathrm{LiP})$, manganese peroxidases $(\mathrm{MnP})$, versatile peroxidases $(\mathrm{VP})$ and dye-decolorizing (DyP-type) peroxidases [44, 45]. These major lignin-degrading enzymes are assisted by fungal accessory enzymes. One group of accessory enzymes are oxidases, e.g. aryl-alcohol oxidase and glyoxal oxidase $[46,47]$. They produce peroxide, which is essential for peroxidase activity. Other accessory enzymes include dehydrogenases that reduce ligninderived compounds (e.g., aryl-alcohol dehydrogenase and quinone reductase) and those that modify lignin by generating hydroxyl radicals (e.g., cellobiose dehydrogenase) [48-50]. The fungal ligninases are described briefly below and more detailed information can be found in reviews focusing on this topic [34, 35, 45, 51, 52]. A generalized scheme for lignin biodegradation that summarizes the enzymatic reaction cycles is provided by Martínez et al. [53].

Laccases catalyze the oxidation of polyphenols and methoxy-substituted phenols by generating free radicals [54]. The oxidation is typically coupled with the reduction of molecular oxygen to water [51]. In the presence of redox mediators, laccases can even catalyze the breakdown of non-phenolic lignin structures, including the cleavage of $\beta$-O-4 linkages [55, 56]. Typical mediators in laccase-mediator systems include 2,2'-azino-bis(3-ethylbenzothiazoline-6sulfonic acid) (ABTS), 1-hydroxybenzotriazole (1-HBT) and the natural mediator acetosyringone (4-hydroxy-3,5-dimethoxyacetophenone) [55-58].

Lignin peroxidases catalyze the oxidative depolymerization of lignin with $\mathrm{H}_{2} \mathrm{O}_{2}$ acting as the oxidizing agent. These enzymes are relatively nonspecific, and can therefore oxidize phenolic aromatic substrates as well as various non-phenolic lignin model compounds [59-61]. The importance of lignin peroxidases for lignin depolymerization reflects their ability to catalyze the cleavage of $\alpha, \beta$ and $\beta$-ether bonds (including $\beta-\mathrm{O}-4$ linkages) leading to the efficient degradation of lignin into mono-aromatic structures, which has been demonstrated using lignin model compounds [61]. For example, synthetic hardwood lignin (molecular weight $>1800 \mathrm{Da}$ ) was degraded into fragments with an average molecular weight as low as $\sim 170$ Da [62].

Manganese peroxidases use $\mathrm{H}_{2} \mathrm{O}_{2}$ to oxidize $\mathrm{Mn}^{2+}$, which is present in wood and soils, thus generating reactive $\mathrm{Mn}^{3+}$ ions. The latter are stabilized by chelators and act as diffusive chargetransfer mediators which are able to oxidize a large number of phenolic substrates [45]. The catalytic mechanism consists of two consecutive one-electron oxidation steps with intermediate cation radical formation [35]. In contrast to lignin peroxidases, manganese peroxidases under normal conditions cannot catalyze the oxidation of more recalcitrant non-phenolic structures [52]. However, a purified manganese peroxidase from P. chrysosporium can oxidize even non-phenolic lignin model compounds in the presence of the detergent Tween-80, which acts as radical mediator [63]. 
Versatile peroxidases combine the properties of lignin peroxidases and manganese peroxidases, conferring the catalytic versatility inferred by their name. They can oxidize $\mathrm{Mn}^{2+}$ to $\mathrm{Mn}^{3+}$ like manganese peroxidases, but can also oxidize non-phenolic compounds in the same manner as lignin peroxidases $[64,65]$.

In contrast to the other three classes of heme peroxidases described above, DyP-type peroxidases are not members of the classical plant/microbial peroxidase superfamily, due to differences in sequence, structure and function $[66,67]$. Therefore, they represent an additional superfamily of heme-containing peroxidases. They were first identified in fungi and later in bacteria $[68,69]$. DyP-type peroxidases show considerable potential for the degradation of lignin because they oxidize dyes, non-phenolic lignin model compounds (including veratryl alcohol and adlerol) and non-phenolic lignin model compounds containing $\beta-\mathrm{O}-4$ linkages $[66,68]$.

\subsubsection{Bacterial lignin degradation}

Whereas fungal lignin degradation has been investigated extensively, bacterial ligninolysis and the corresponding enzymes have received comparatively little attention [70, 71]. Bacterial wood decay was initially considered more as a challenge for forestry than a biotechnological opportunity [72]. The classes of ligninolytic enzymes found in fungi play no role in bacterial ligninolysis, apparently reflecting the complexity of the fungal proteins and the need for posttranslational modifications, which are largely absent in bacteria [11]. Genomic and proteomic analysis in ligninolytic bacteria has confirmed the absence of $\mathrm{LiP}, \mathrm{MnP}$ and $\mathrm{VP}$ enzymes $[73,74]$, whereas bacterial laccases and DyP-type peroxidases have been identified [75, 76]. DyP-type peroxidases are less complex than the other heme peroxidases and are common among bacteria [11, 44], including the extracellular enzyme systems of Thermobifida fusca and Rhodococcus jostii [69, 77]. Several bacterial laccases have also been identified [78-80] including multiple laccase-like multi-copper oxidases in Agromyces salentinus and Sinorhizobium morelense [78]. Even if the knowledge concerning bacterial peroxidases and laccases has grown recently, additional-as yet undiscovered-enzymes may be required for bacterial lignin degradation, for example, oxidases for the production of $\mathrm{H}_{2} \mathrm{O}_{2}$.

Whereas large-scale lignin degradation by fungal enzymes has been hampered by the complexity of the enzymes and the challenges of fungal genetic modification and protein expression, the simpler bacterial DyP-type peroxidases and laccases are promising targets for enzyme development [11, 19, 75]. In contrast to fungal peroxidases, several bacterial DyPtype peroxidases and laccases have been expressed at high levels in Escherichia coli [81, 82] and efficient lignin degradation has been demonstrated for DyP-type peroxidases [83]. For example, a bacterial DyP-type peroxidase expressed in a gene deletion strain of Rhodococcus jostii (its native producer) efficiently degraded wheat straw lignocellulose and produced vanillin and small amounts of ferulic acid and 4-hydroxybenzaldehyde [83]. Such processes have proven feasible in the laboratory, and the next challenge is to scale up production to industrial levels. 


\subsubsection{Applications of enzymatic lignin degradation}

As stated above, lignin is widely treated as a waste product, and industrial ligninolytic processes have until recently focused on removing lignin and valorizing the remaining cellulose and hemicellulose rather than exploiting the lignin itself. The applications of industrial scale enzymatic lignin degradation (ELD) also tend to focus on lignin removal. Biopulping in pulp and paper industries or for ethanol production in biorefineries is an example for such an ELD process [84, 85].

Biopulping can be defined as a pre-treatment method of wood chips with lignin-degrading fungi prior to the main pulping process $[85,86]$. The main aim of biopulping is to soften the wood before the main pulping process through lignin modification or its removal [87]. The establishment of biopulping as a pre-treatment prior to mechanical and chemical pulping offers the potential to make the entire process more economical and sustainable, because biopulping can reduce the consumption of chemicals and energy (shorter cooking time) in the subsequent chemical pulping stage, and can also improve pulp quality and paper strength [87, 88]. White-rot fungi such as C. subvermispora are typically used in this context [89].

Another industrial ELD process discussed for industrial application is biobleaching. This process applies enzymes or ligninolytic fungi for the bleaching of pulps. Bleaching removes color from the wood pulp (much of which is derived from lignin and its degradation products) and biobleaching involves the application of ligninolytic microbes or their enzymes to achieve this outcome. Biobleaching is less environmentally harmful than conventional chlorine-based bleaching because it does not involve the use of bleaching chemicals and the formation of hazardous byproducts. The success of bleaching is measured by the decrease in lignin content (kappa number) and the increase in pulp brightness. Promising results have been achieved by using laccase-mediator systems on eucalyptus kraft pulp, e.g. bacterial laccase produced by Streptomyces cyaneus CECT 3335 in the presence of the mediator ABTS [58, 90].

The simultaneous removal and valorization of lignin can be achieved by enzymatic lignin degradation and product recovery in an EMRS (Figure 4). Compared to conventional reaction systems, an EMRS offers advantages such homogeneous catalysis, the use of free enzymes and complete biocatalyst retention and recycling [91]. An EMRS also allows the continuous separation of low-molecular weight products from high-molecular weight substrate and catalyst molecules, thus preventing the re-polymerization of target products. The biocatalyst is simple to replace (according to enzyme inactivation rates), which achieves stable substrate conversion rates [92]. EMRS processes have also been tested for the continuous removal of endocrine disrupting compounds from wastewater, using versatile peroxidases and polyethersulfone (PES) ultrafiltration membranes [93, 94].

An ERMS comprises two main parts: a reactor unit for enzymatic conversion and a filtration unit for enzyme/substrate retention and product removal. Therefore, the development of an EMRS process for enzymatic lignin degradation and the purification of aromatic monomers must focus on both the enzyme kinetics of the reactor unit and the filtration performance of the separation unit. 


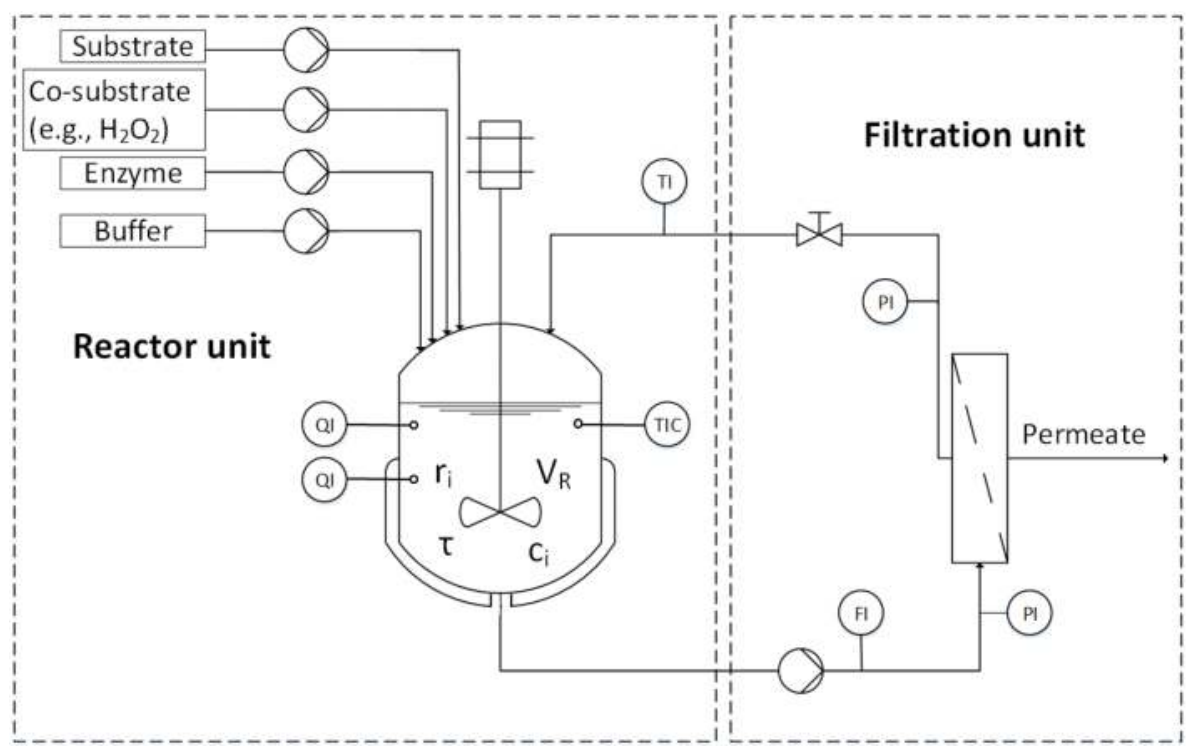

Figure 4. Schematic representation of an enzyme membrane reactor system (EMRS) including a continuous stirred-tank reactor and a filtration unit in crossflow operational mode (adapted from [91]).

Enzyme kinetics: successful EMRS bioprocess design requires the enzyme reaction kinetics to be understood in detail. The reaction kinetics of a crude versatile peroxidase from Bjerkandera adusta as a ligninolytic model peroxidase was recently investigated during the degradation of adlerol (a $\beta-O-4$ lignin model dimer) [95]. The crude enzyme showed saturation kinetics for adlerol degradation following the Michaelis-Menten equation, and was sensitive to $\mathrm{H}_{2} \mathrm{O}_{2}$. However, inactivation by $\mathrm{H}_{2} \mathrm{O}_{2}$ could be reduced by increasing the amount of adlerol substrate. The authors recommended that $\mathrm{H}_{2} \mathrm{O}_{2}$ concentrations should be kept below $50 \mu \mathrm{M}$ at a substrate $/ \mathrm{H}_{2} \mathrm{O}_{2}$ ratio of 15:1. Continuous lignin degradation in such a reactor would therefore require carefully controlled slow $\mathrm{H}_{2} \mathrm{O}_{2}$ feeding rates [95].

Filtration performance: an appropriate membrane is crucial for the design and productivity of EMRS processes because the filtration performance influences process parameters such as the hydraulic retention time $(\tau)$, the input of substrate and oxidizing agent $\left(\mathrm{H}_{2} \mathrm{O}_{2}\right.$ for peroxidases), and therefore the enzyme reaction kinetics and substrate conversion rates [92, 96]. Importantly, the performance and productivity of membrane filtration systems are reduced by fouling, which increases membrane resistance and reduces flux due to the formation of unwanted deposits on the membrane surface and/or in the membrane pores [97, 98]. Extensive fouling may be caused, among others, by proteins, polysaccharides and polydisperse technical lignin, all of which are present during the enzymatic degradation of lignocellulosic biomass [92, 97]. Accordingly, the filtration performance of membranes used in delignification reactions must be robustly tested, including their fouling and separation characteristics. Such tests were recently reported for a ceramic ultrafiltration membrane exposed to a model reaction mixture containing a commercial polydisperse lignosulfonate substrate, guaiacol as a model degradation product, and ovalbumin 
as a model biocatalyst in place of the genuine versatile peroxidase [92]. As anticipated, the flux declined significantly during filtration but reached steady-state levels within $1 \mathrm{~h}$, and the flux could be improved by $50 \%$ by increasing the crossflow velocity from 0.2 to $1 \mathrm{~m} / \mathrm{s}$. The latter indicated that fouling was reversible rather than irreversible, as confirmed by the rapid and efficient cleaning. The retention and separation characteristics of the filtration system were controlled primarily by the substrate concentration rather than the protein load and hydrodynamics. The retention of lignosulfonates using a $5 \mathrm{kDa}$ membrane remained stable at $80-90 \%$ under all conditions, whereas the retention of the model product guaiacol increased with the lignosulfonate load. The authors noted that the retention of degradation products should be avoided because this can lead to undesirable enzyme inactivation or polymerization reactions if real enzymes are used instead of the model ovalbumin [92]. Based on the results summarized above $[92,95]$ in silico investigations were carried out to predict the flux needed to maximize the product yield during the enzymatic oxidation of lignin model compounds in a continuous EMRS process. The authors evaluated an optimal permeate flux of $4 \mathrm{~L} \mathrm{~m}^{-2} \mathrm{~h}^{-1}$ for the previously used $5 \mathrm{kDa}$ membrane [96].

More recently, the $\mathrm{H}_{2} \mathrm{O}_{2}$-dependent reaction/inactivation kinetics of the crude versatile peroxidase from B. adusta [95] and the filtration performance data described above (retention coefficients and optimum permeate flux) [92, 96] were combined to model the design and operational mode of a continuous membrane reactor for enzymatic lignin modification [91]. Fed-batch experiments were used to determine starting concentrations for adlerol and $\mathrm{H}_{2} \mathrm{O}_{2}$, allowing the dynamic analysis of the kinetics with and without the continuous addition of the enzyme. The resulting model EMRS for the modification of lignin-related substrates by versatile peroxidases simulated the behavior of fed-batch and continuous processes, enabling process development, process design and process optimization. The authors concluded that the modification of technical lignin using versatile peroxidase in an EMRS is a promising approach, with membrane fouling and $\mathrm{H}_{2} \mathrm{O}_{2}$ sensitivity in an acidic milieu as major challenges that remain to be addressed [91]. Ceramic membranes were preferred in these studies [91, 92, 96] due to their advantages over polymeric membranes, particularly their greater chemical and thermal stability which allows the filtration of acids, bases, solvents and hot feeds, and allows them to survive the harsh cleaning conditions that are often necessary to restore membrane permeability. Ceramic membranes also maintain physical stability during the filtration of abrasive media and generally last longer than polymeric membranes [99, 100].

\subsubsection{Conclusion and outlook}

A comprehensive understanding of natural lignin degradation pathways is necessary for the development of effective bioprocesses based on ELD. Much is already known about fungal lignin degradation and the corresponding enzymes, but more work is required to understand bacterial lignin degradation. Biopulping and biobleaching are useful applications of ELD, but these are used to replace or support conventional pulping and bleaching processes rather than to valorize lignin by isolating its degradation products. ELD and product recovery can be achieved using an EMRS, which allows continuous processing and product removal. Busse and colleagues have studied EMRS-based lignin degradation in detail, including the use of a crude versatile peroxidase $[91,92,95,96]$, but the industrial application of peroxidase-based 
bioprocesses has not yet been realized [101]. Progress is hampered by the low availability of peroxidases in sufficient amounts, $\mathrm{H}_{2} \mathrm{O}_{2}$-related enzyme instabilities and high enzyme cost $[102,103]$. Future research should focus on the development of cost-effective enzyme production systems (homologous and/or heterologous), and protein engineering to improve enzyme performance and reduce $\mathrm{H}_{2} \mathrm{O}_{2}$ sensitivity [101, 102]. Potential expression systems include bacteria (E. coli), yeast (Saccharomyces cerevisiae and Pichia pastoris) and fungi (particularly white-rot fungi and Aspergillus spp.) [104, 105] but none of these systems yet fulfills the requirements for industrial applications [105]. Alternatively, bacterial DyP-type peroxidases could be used for lignin valorization. The promising lignin degradation abilities of bacterial DyP-type peroxidases and the possibility to produce them-potentially more efficient than fungal peroxidaes-by recombinant expressions systems makes them interesting candidates for lignin utilization.

\subsection{Photocatalytic degradation}

\subsubsection{Basic principles of photocatalysis}

Photocatalysis is one of a special class of oxidation technologies known as advanced oxidation processes, which are characterized by the production of extraordinarily reactive hydroxyl radicals (OH radicals). These attack most organic molecules with rate constants usually in the order of $10^{6}-10^{9} \mathrm{M}^{-1} \mathrm{~s}^{-1}$, which is several times higher than other reactive oxidizing agents such as ozone (Table 2). In addition to their reactivity, hydroxyl radicals are relatively nonselective, which makes advanced oxidation processes ideal for applications involving heterogeneous systems such as wastewater and industrial lignin [106].

Heterogeneous photocatalysis requires a semiconductor material that is irradiated with light. The absorption of light on the semiconductor surface generates electron-hole pairs by exciting electrons from the valence band to the conduction band of the semiconductor (Figure 5) [109]. Once the electron-hole pairs form, there is a period of time in the range of nanoseconds during which charge can be transferred to adsorbed species on the semiconductor surface [110]. The energy of the applied light source must be equal to or greater than the band-gap energy of the

\begin{tabular}{lll}
\hline & \multicolumn{2}{c}{ Rate constant $\left(\mathbf{M}^{-1} \mathbf{~ s}^{-1}\right)$} \\
\cline { 2 - 3 } Organic compound & OH radical & Ozone $\left(\mathbf{O}_{3}\right)$ \\
\hline Benzene & $7.8 \times 10^{9}$ & 2 \\
Chlorobenzene & $4.5 \times 10^{9}$ & 0.75 \\
Toluene & $6.8 \times 10^{9}$ & 14 \\
Styrene & $6 \times 10^{9}$ & $3 \times 10^{5}$ \\
n-Butanol & $4.6 \times 10^{9}$ & 0.6 \\
n-Propanol & $2.2 \times 10^{9}$ & 0.4 \\
\hline
\end{tabular}

Table 2. Rate constants for the reaction of hydroxyl radicals and ozone with different organic compounds (reproduced from Refs. [107, 108]). 


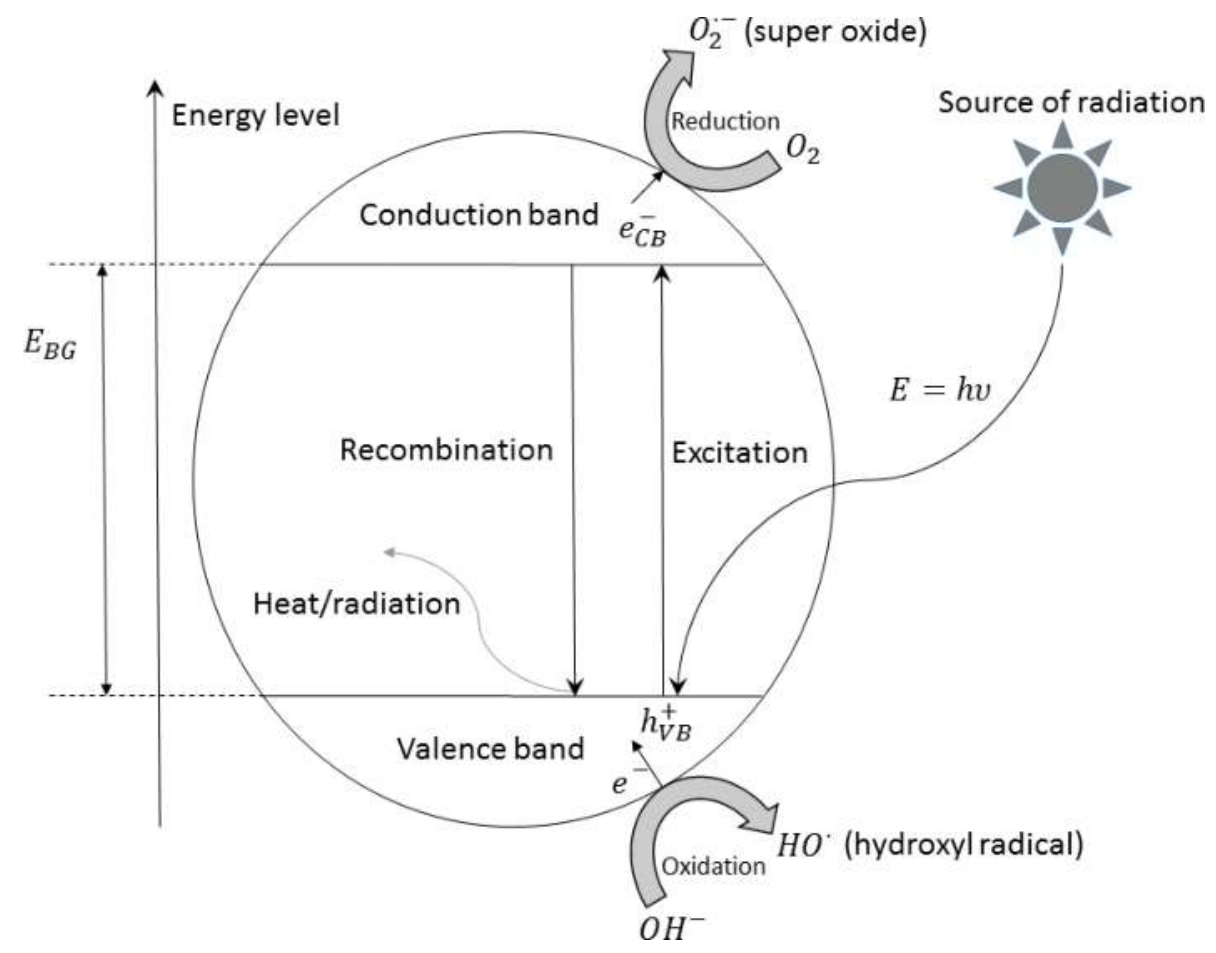

Figure 5. Schematic representation of primary steps during photocatalysis, adapted and modified from [111].

semiconductor $\left(\mathrm{E}_{\mathrm{BG}}\right.$, energy difference between the valence and conduction bands) in order to form the electron-hole pairs [109].

Photocatalysis is typically carried out using semiconductor metal oxides, usually $\mathrm{TiO}_{2}$, which is the most efficient and stable photocatalyst, and also the least expensive among the available materials. $\mathrm{TiO}_{2}$ is nontoxic, and chemically and biologically inert, making it the only material suitable for current and probably also future industrial applications [112]. The three main types of $\mathrm{TiO}_{2}$ are rutile, anatase and brookite, with most semiconductors based on anatase or brookite [113]. Band-gap energies are approximately $3.0 \mathrm{eV}$ for rutile and $3.2 \mathrm{eV}$ for anatase [114]. ZnO photocatalysts have also been used in several studies [115-117].

The fundamental reaction principle of photocatalysis is based on the generation of highly reactive species by the reaction of photogenerated electrons or holes with water, hydroxyl ions or oxygen, resulting in the oxidation and degradation of organic substrates [118]. Photogenerated electrons and holes can follow different reaction pathways, and multiple substrate-degrading mechanisms may co-occur depending on the nature of the substrates, the semiconductor material and several other parameters. A useful overview of the pathways involved in photocatalytic reactions is provided by Hoffmann et al. [119]. Photogenerated holes (Eq. (1)) partake in oxidation reactions with water or adsorbed hydroxyl ions to generate hydroxyl radicals (Eqs. (2) and (3)) that oxidize organic substrates (Eq. (5)). Another possibility 
is the direct oxidation of adsorbed substrate molecules by photogenerated holes (Eq. (4)) yielding oxidized substrate radicals, which may in turn partake in multiple consecutive reactions (e.g., Eq. (6)) [111].

Photogenerated electrons can chemically reduce dissolved molecular oxygen in aerated aqueous solutions (Eq. (7)) and in doing so generate superoxide radicals or singlet oxygen (Eqs. (7) and (8)). Hydrogen peroxide and hydroxyl radicals can also be formed via oxygen reduction pathways. In consecutive reactions, the reactive species created by photogenerated electrons can oxidize organic substrates as well as photogenerated holes [113, 119]. In addition to desirable degradation reactions, electrons and holes may recombine, which is associated with the dissipation of heat and/or radiation (Eq. (9)). Electron-hole recombination reduces the number of electron-hole pairs, and therefore the photocatalytic efficiency. This undesirable effect has been demonstrated for $\mathrm{TiO}_{2}$-based catalysts [120].

$$
\begin{gathered}
\mathrm{TiO}_{2} \stackrel{h v \geq E_{B G}}{\longrightarrow} \mathrm{TiO}_{2}\left(e_{\mathrm{CB}}^{-}+h_{V B}^{+}\right) \\
\mathrm{TiO}_{2}\left(h_{V B}^{+}\right)+\mathrm{H}_{2} \mathrm{O} \rightarrow \mathrm{TiO}_{2}+\mathrm{HO}^{\circ}+H^{+} \\
\mathrm{TiO}_{2}\left(h_{V B}^{+}\right)+\mathrm{OH}^{-} \rightarrow \mathrm{TiO}_{2}+\mathrm{HO} \\
\mathrm{TiO}_{2}\left(h_{V B}^{+}\right)+\mathrm{S} \rightarrow \mathrm{TiO}_{2}+\mathrm{S}^{+} \\
\mathrm{S}+\mathrm{HO} \rightarrow \mathrm{S}^{+}+\mathrm{OH}^{-} \\
S^{+}+\mathrm{O}_{2} \rightarrow \mathrm{SO}_{2}^{+} \\
\mathrm{TiO}_{2}\left(e_{\mathrm{CB}}^{-}\right)+\mathrm{O}_{2} \rightarrow \mathrm{TiO}_{2}+\mathrm{O}_{2}^{--} \\
\mathrm{HO}+\mathrm{O}_{2}^{--} \rightarrow \mathrm{OH}^{-}+{ }^{1} \mathrm{O}_{2} \\
\mathrm{TiO}_{2}\left(e_{\mathrm{CB}}^{-}\right)+\mathrm{TiO}_{2}\left(h_{V B}^{+}\right) \rightarrow \text { heat } / \text { radiation }
\end{gathered}
$$

\subsubsection{Photocatalytic lignin degradation}

The precise comparison of studies involving photocatalytic lignin degradation (PLD) is difficult due to differences in the lignin source, photocatalyst type, sample $\mathrm{pH}$, reactor design, illumination source, radiation intensity and analytical method used in each study. However, it is possible to make general statements about the fundamental scientific findings.

The first interest in PLD resulted from the knowledge that lignin and its derivatives are the main source of chemical oxygen demand (COD) in the wastewater from pulp and paper mills and are also responsible for the undesirable brown color of these effluents. Because both the COD and color intensity of discharged effluents are subject to strict regulations, the degradation of lignin in wastewater is an important requirement. Furthermore, applied activated sludge processes cannot completely decompose lignin or its degradation products. The undesirable brown color remaining after the activated sludge processes can only be reduced by repeating the process, which is expensive. For these reasons, PLD has been investigated as a possible alternative for color and COD removal in wastewater [117, 121]. 


\subsubsection{Lignin derived from the cooking stage}

The first studies dealing with heterogeneous PLD applied to technical lignin solutions from pulp and paper mills $[117,121]$ provided fundamental insights into lignin degradation by photocatalysis. The authors observed a significant decrease or complete removal of COD and color, suggesting the complete degradation of lignin into inorganic compounds such as carbon dioxide, carbon monoxide and water. Therefore, they proved that semiconductor photocatalysis efficiently decomposes kraft and alkaline lignins from the cooking stage. The basic principles of PLD were also confirmed in these pioneering studies. Ohnishi et al. [117] found that semiconductor photocatalysis applied in the dark without a source of radiation did not remove color at all, and combined with that lignin degradation and color loss did not occur in the absence of photocatalyst, even with prolonged illumination. These results have been confirmed in more recent studies [115, 116, 122, 123]. The important role of oxygen in PLD was also confirmed [117, 121]. Reducing the oxygen supply resulted in slower lignin degradation, and in the absence of oxygen there was no degradation at all. Oxygen therefore appears to promote the degradation process by accepting electrons from the conduction band of the semiconductor material (Figure 5 and Eq. (7), Eq. (8)) [117, 121].

The photocatalytic degradation of alkaline lignin using different photocatalytic materials (e.g., $\mathrm{TiO}_{2}, \mathrm{ZnO}$ and $\mathrm{CdS}$ ) has also been investigated, applying a $500 \mathrm{~W}$ high-pressure mercury lamp as the radiation source [117]. The authors focused on complete lignin degradation rather than the formation of valuable mono-aromatic compounds during photocatalysis. They found that the most suitable semiconductor material depends on the $\mathrm{pH}$ of the treated lignin solution, and that catalytic efficiency improved when noble metals such as Pt, Ag or Au were combined with $\mathrm{TiO}_{2}$ photocatalysts [117].

\subsubsection{Lignin from the bleaching stage}

Following the cooking stage, the bleaching process also creates process streams containing lignin (Figure 3). Bleaching is carried out to remove residual lignin from the pulp because paper containing lignin has a light brown color and the residual lignin causes undesirable photo-yellowing as the paper ages [124]. Bleaching is often achieved using oxidative chlorine compounds, but more environmentally sustainable options include total chlorine-free bleaching, which involves oxygen, hydrogen peroxide or ozone [125] and the biobleaching process discussed above $[58,90]$. Bleaching with chlorine compounds is environmentally hazardous particularly due to the formation of absorbable organic halogens [126], including chlorinated lignin-related compounds [127]. Bleached effluents must therefore be treated before discharge into the environment. Several different setups have been used to achieve the photocatalytic oxidation of organic compounds in bleaching effluents from pulp and paper mills [122, 123, 128]. For example, a combination of suspended $\mathrm{TiO}_{2}$ particles and $\mathrm{H}_{2} \mathrm{O}_{2}$ has been used for the photocatalytic oxidation of softwood kraft pulp bleach effluents from different stages (raw, biologically pretreated and coagulated) [128]. Photocatalytic oxidation achieved more efficient COD reduction in pretreated wastewater samples than raw kraft bleaching effluents. In contrast to the early studies discussed above which used lignin from the cooking stage $[117,121]$, the complete removal of COD from bleached 
effluents was not possible, and complete color removal was only achieved for coagulated wastewater samples [128]. Furthermore, free $\mathrm{TiO}_{2}$ and $\mathrm{ZnO}$ or silica gel/porcelain-supported $\mathrm{ZnO}$ achieved considerable color clearance as well as the removal of phenols [123]. The efficiency of color clearance differed between the free and supported catalysts, mainly reflecting the better physical adsorption of organic compounds to suspended particles compared to those supported on a substrate [123]. Tanaka et al. [129] revealed that photocatalysis is accompanied by the adsorption of organic molecules onto the photocatalyst surface. Lignin was rapidly adsorbed onto the $\mathrm{TiO}_{2}$ catalyst surface and subsequent illumination caused simultaneous desorption and degradation. Therefore adsorption, desorption and degradation must all be taken into account when designing a photocatalytic degradation process [129]. Yeber et al. [122] tested $\mathrm{TiO}_{2}$ and $\mathrm{ZnO}$ supported on glass Raschig rings, and observed the complete removal of color, a substantial reduction in phenol levels and significantly lower toxicity following treatment. All these data indicate that the applicability of heterogeneous photocatalysis is not limited to lignin solutions from the cooking stage but can also be applied to effluents from the bleaching stage. Interestingly, the first applications of immobilized photocatalyst systems were introduced in this context [122, 123] as discussed in more detail below.

\subsubsection{Immobilized photocatalytic systems}

Immobilized systems combine a photocatalytic layer with a support material. The main advantages of immobilized systems compared to suspended photocatalyst particles include the reuse of the catalyst without downstream recovery steps (which increase upfront and operating costs) and reduced catalyst leakage. Potential disadvantages include the lower photocatalytic efficiency due to mass transfer limitations [130]. However, well-designed hydrodynamic operating conditions can address mass transfer limitations and restore high photocatalytic efficiency [115].

A particularly successful application of immobilized photocatalysts for PLD involved a ZnO photocatalyst fixed on pumice stone for the degradation of lignin solutions prepared by the precipitation of lignin from black liquor (kraft lignin). The experiments were conducted under solar illumination and achieved 98\% lignin degradation after $2.5 \mathrm{~h}$ [116]. These operating conditions are cost efficient for two reasons: the immobilized catalyst removes the need for a downstream recovery step and the solar illumination is free, making such systems highly suitable for the treatment of wastewater produced by the pulp and paper industry. A comprehensive comparative analysis of $\mathrm{TiO}_{2}$ coatings on sintered glass particles (grain size $=200$ $400 \mu \mathrm{m})$ packed in a borosilicate tube $(26 \mathrm{~cm}$ long, $1 \mathrm{~cm}$ outer diameter, $6 \mathrm{~mm}$ internal diameter) was used to study the degradation of lignosulfonates supplied by a paper company [115]. The study compared several catalysts $\left(\mathrm{TiO}_{2}-\mathrm{P} 25-\mathrm{SiO}_{2}+\mathrm{Pt}, \mathrm{TiO}_{2}-\mathrm{P} 25-\mathrm{SiO}_{2}, \mathrm{ZnO}+\mathrm{TiO}_{2}-\right.$ $\mathrm{P} 25-\mathrm{SiO}_{2}$ and $\mathrm{TiOSO}_{4} \_30.6 \mathrm{wt} \%$ ) using established synthesis and coating procedures [131]. The study set out not only to address the lignin-related problems of COD and color removal in pulp and paper mill wastewater, but also to evaluate the formation of valuable products during photodegradation. The operation mode included an integrated solid-phase extraction and dialysis membrane in order to directly extract smaller molecules, preferably aromatic and phenol-like compounds, from the aqueous solution (Figure 6). 


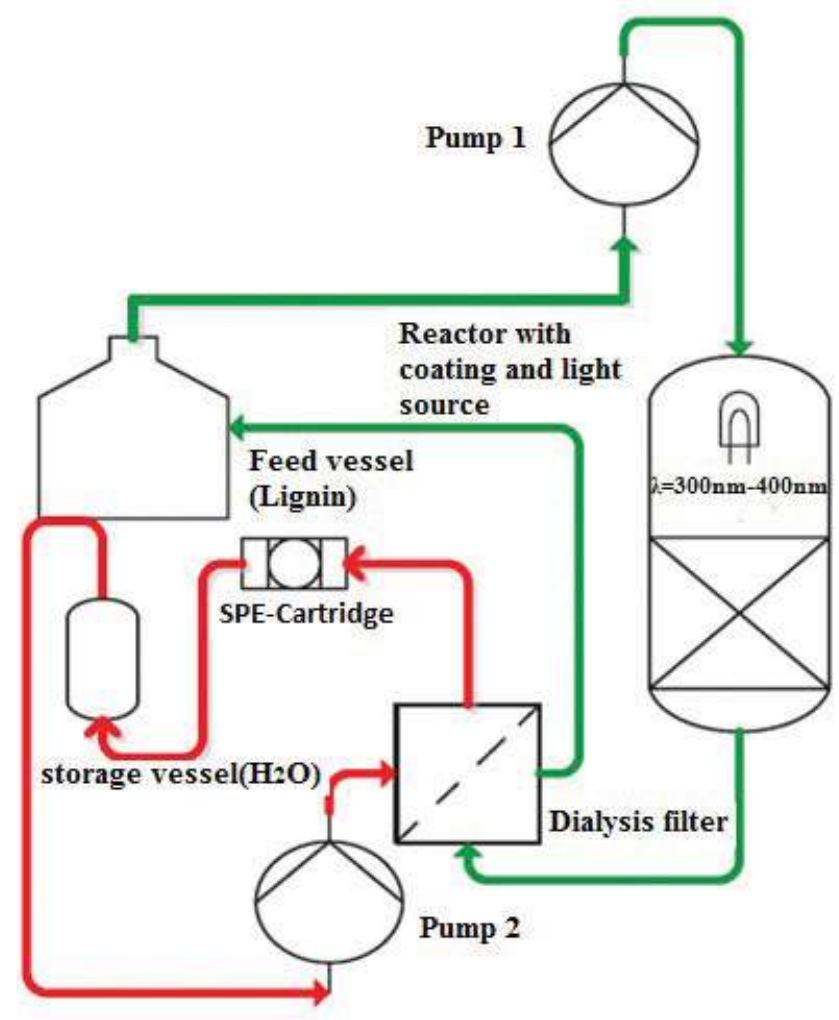

Figure 6. Photocatalytic lignin degradation with integrated solid-phase extraction and dialysis membrane (reprinted with permission [115]).

This study confirmed the effective degradation of relatively high concentrations of lignosulfonates $(500 \mathrm{mg} / \mathrm{L})$ and indicated that potential high-value degradation products were formed, although these products were not identified or quantified [115]. The strategy of continuously isolating target products from the reaction mixture during photocatalytic degradation using a combination of solid-phase extraction and dialysis is an interesting approach for the production of aromatic products by PLD. Further research is needed to reveal the nature of the isolated molecules, and quantification would help to determine the economic viability of such processes.

\subsubsection{Mechanistic aspects and potential products}

The formation of mono-aromatic products during PLD has been described in several studies. Miyata et al. [132], using defatted Picea glehnii wood flour (softwood) as a substrate, confirmed the formation of vanillin during PLD process using H-NMR analytics. The amount of vanillin was not determined, but the authors suggested a PLD reaction mechanism including the cleavage of $\mathrm{C} \alpha-\mathrm{C} \beta$ bonds [132]. In another study focusing not only on COD removal but also 
on the potential formation of intermediates such as vanillin, a $\mathrm{TiO}_{2}$ (rutile) photocatalyst was applied to softwood-derived kraft lignin [121]. Aromatic compounds originating from the kraft lignin solution (e.g., vanillin and catechol) could not be recovered because most aromatic monomers were dimerized at the beginning of photocatalysis, and were completely decomposed as the reaction proceeded [121]. Similar results were reported for a $\mathrm{TiO}_{2}$ (anatase) photocatalyst applied to lignosulfonates from coniferous wood (softwood): lignin fractions were first polymerized and then converted into smaller molecules during the photocatalytic process, ultimately leading to complete mineralization [129]. In the same study, Fouriertransform infrared spectroscopy showed that the aromatic moiety was transformed more rapidly than the aliphatic side chains [129]. The opposite was found for photocatalytic degradation of lignosulfonate using UV-Vis spectroscopy: the absorption peaks at 203 and $280 \mathrm{~nm}$ were associated with unsaturated chains and unconjugated phenolic hydroxyl groups/aromatic rings, respectively [115].

\subsubsection{Conclusion and outlook}

The large-scale photocatalytic production of aromatic compounds from industrial lignin has not yet been reported. Most PLD research has focused on COD and color removal during wastewater treatment, whereas few reports consider the recovery of valuable aromatic products. Lekelefac and Czermak [115] used a combination of solid-phase extraction and dialysis for the continuous isolation of desired products from the reaction mixture during PLD, but this is an exceptional approach. The development of heterogeneous PLD processes that also produce mono-aromatic compounds will require intense scientific research because PLD ultimately results in the complete mineralization of lignin, and the mechanistic principles discovered thus far imply a polymerization-depolymerization mechanism in which the reaction conditions and especially the residence times have a strong impact on the yields of desirable mono-aromatic products. Given the heterogeneity of lignin and the multiple PLD reaction pathways, a broad mixture of products can be expected. Efficient and cost-effective separation technologies for product recovery would therefore play a key role in the successful development of PLD processes. In the foreseeable future, the main application of heterogeneous PLD is likely to remain the complete mineralization of lignin to reduce COD and remove color from wastewater.

\subsection{Thermochemical lignin degradation}

\subsubsection{Lignin pyrolysis}

Pyrolysis is the thermal treatment of a feedstock in absence of oxygen with or without a catalyst, similar to the cracking process applied in petroleum refineries. The aim of pyrolysis is to break down the molecular structure of the feedstock to smaller components while the absence of oxygen prevents combustion to carbon dioxide and water [5, 133]. The pyrolysis of biomass results in the formation of gases, liquid oils and a thermally stable solid fraction known as char [133]. The pyrolysis of lignin generates gaseous hydrocarbons including carbon monoxide and carbon dioxide, as well as monolignols (e.g., coniferyl alcohol), monophenols (e.g., phenol and guaiacol), polysubstituted phenols and 
char [5]. The ratio of products depends on parameters such as the heating rate, temperature, pressure and type of lignin feedstock (e.g., lignocellulosic biomass, kraft lignin or lignosulfonate) [134-136].

\subsubsection{Hydrogenolysis}

Pyrolysis in the presence of hydrogen is described as hydrogenation or hydrogenolysis. Gaseous hydrogen and hydrogen-donating solvents such as tetralin or common alcohols have been used for the hydrogenolysis of lignin and lignocellulosic biomass [137-141]. During this process, the cleavage of bonds is assisted by the addition of hydrogen, which results in the reductive conversion of lignin. These reductive reaction characteristics of hydrogenolysis tend to reduce or remove functionality in lignin ultimately leading to simpler phenols [2]. Therefore, hydrogenolysis is a promising method for the production of bulk phenolic chemicals from lignin [2, 5, 142]. A large number of heterogeneous metal-based catalysts (e.g., Ni, Rh, $\mathrm{Ni}-\mathrm{Mo}, \mathrm{Co}-\mathrm{Mo}$ and $\mathrm{Pd}$ ) and a significant smaller number of homogeneous catalysts have been combined with the hydrogenolysis of different lignin models, technical lignins or lignocellulosic biomass [2, 141, 143]. An exhaustive review of applied catalyst was published by Zakzeski et al. [2].

\subsubsection{Lignin oxidation}

Unlike photocatalytic lignin oxidation as described above, thermal oxidation involves the application of heat as well as oxidizing agents such as oxygen or hydrogen peroxide, and the reaction conditions and catalysts are distinct. Compared to hydrogenolysis, lignin oxidation leads to more complex aromatic compounds with greater functionality [2]. Lignin oxidation plays an important role in the conversion of lignin to aldehydes such as vanillin and syringaldehyde [13, 144-146]. However, the spectrum of potential products also includes carboxylic acids, aliphatic alcohols and hydrocarbon gases, with the product ratios depending on the lignin source, type of catalyst and reaction conditions [2, 5]. Catalytic lignin oxidation has also been reviewed by Zakzeski et al. [2]. This process offers immense scope for the production of bulk platform chemicals as well as value-added fine chemicals, as shown by the alkaline oxidation of lignosulfonates in air for the production of vanillin [27, 147].

\subsubsection{Separation technology based on ceramic membranes}

Like ELD and PLD, thermochemical lignin conversion produces complex mixtures of degradation products including residual non-degraded lignin substrate. These must be separated to achieve the full valorization of technical lignin derived from industrial processes. Membrane technology is ideal for the recovery of technical lignin from various industrial processes given its unique combination of scalability, economic efficiency and versatility [148]. Therefore, the membrane-based fractionation of reaction mixtures from thermochemical lignin degradation processes could be used to separate non-degraded lignin from valuable mono-aromatic compounds [149]. The key advantages of ceramic membranes include their chemical and thermal stability, which allow the filtration of acids, bases, solvents and hot feeds, and make the membranes resistant to the harsh cleaning conditions that may be necessary to restore 
permeability $[99,100]$. These properties match the requirements of filtration processes involving reaction mixtures from thermochemical degradation, including extreme $\mathrm{pH}$ and the presence of harsh solvents.

We have investigated the fractionation of lignin derivatives (produced using oxygen as the oxidizing agent and methanol as the solvent) using ceramic membranes in order to separate residual lignosulfonate from mono-aromatic compounds. The ceramic membrane we used was a 30-nm hollow fiber membrane (MANN + HUMMEL) with three fibers, a molecular weight cut-off (MWCO) of $\sim 800 \mathrm{kDa}$ (based on our own measurements using polyethylene glycol) and a surface area of $0.0035 \mathrm{~m}^{2}$. The filtration test bench is shown schematically in Figure 7 and comprised two operational modes: dead-end filtration (valve 1 closed) and crossflow filtration (valve 1 open). Tests were carried out in crossflow filtration mode. The permeate flux was measured using an electronic balance and the transmembrane pressure (TMP) was calculated according to Eq. (10) using the pressure gauges $P_{1} I\left(p_{1}\right)$ and $P_{2} I\left(p_{2}\right)$. The pressure on the permeate side $\left(\mathrm{p}_{3}\right)$ was negligible. The tangential crossflow velocity $\left(\mathrm{v}_{\mathrm{CF}}\right)$ was determined by flowmeter data (FI) and membrane geometry.

$$
\mathrm{TMP}=\frac{p_{1}+p_{2}}{2}-p_{3}
$$

The filtration experiments were carried out in batch mode, and a filtration run was deemed complete when $50 \%$ of the original feed was present on the permeate side. The resulting flux

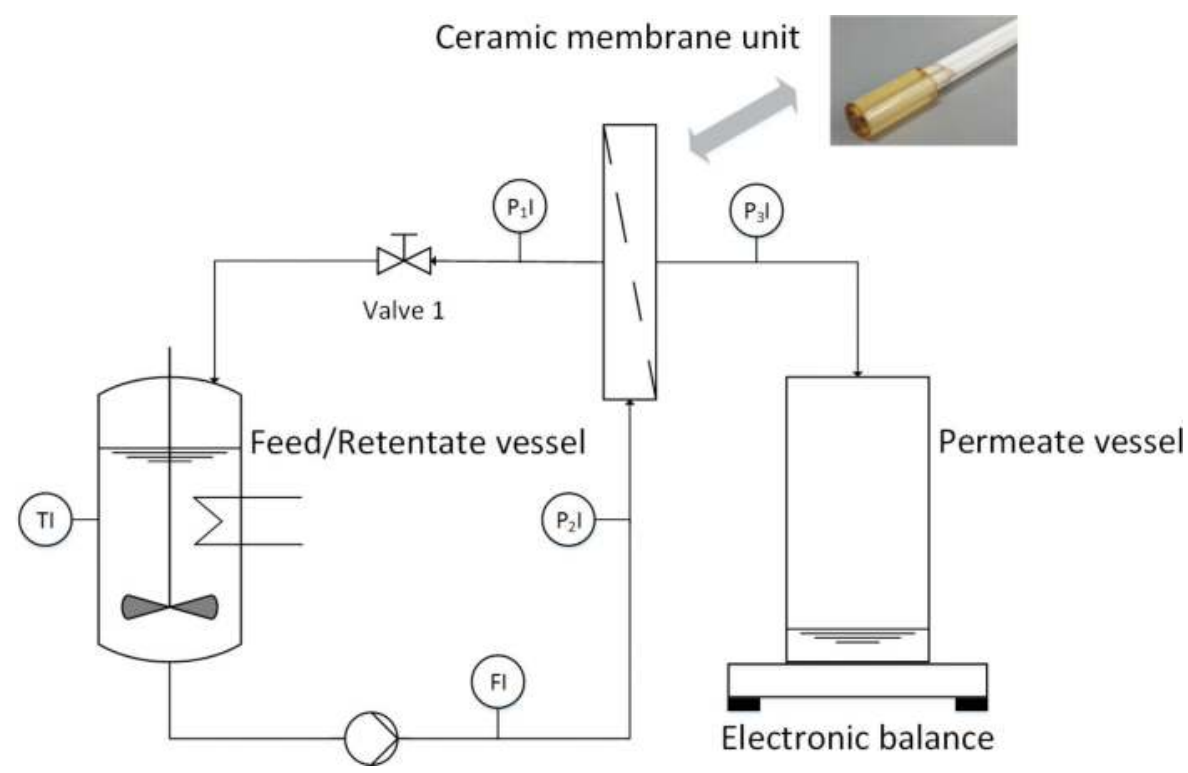

Figure 7. Schematic representation of the membrane filtration system (representative fluid levels in feed/retentate and permeate tanks). 


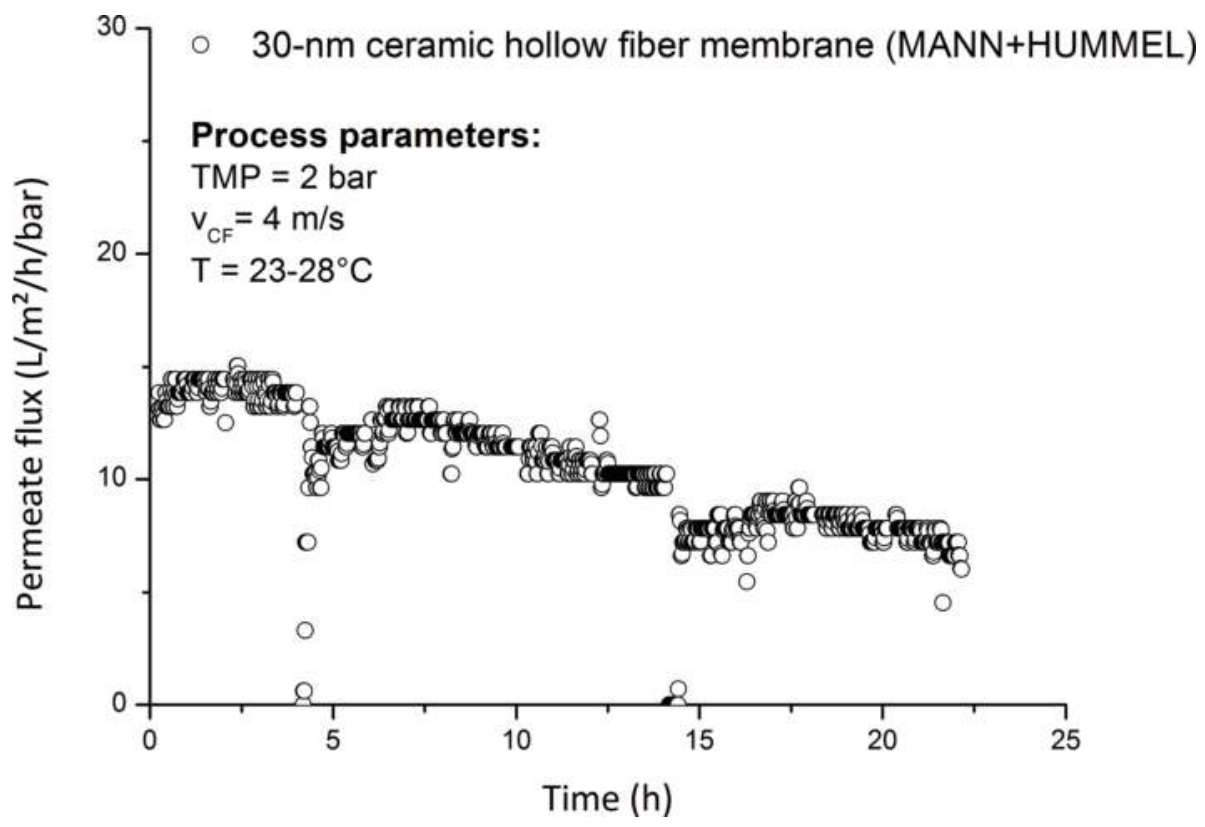

Figure 8. Flux profile during the batch filtration of oxidized lignosulfonate in methanol (TMP $=2 \mathrm{bar}, \mathrm{v}_{\mathrm{CF}}=4 \mathrm{~m} / \mathrm{s}, \mathrm{T}=23-$ $28^{\circ} \mathrm{C}$, 30-nm MANN + HUMMEL ceramic hollow fiber membrane).

profile is shown in Figure 8. The interruptions in the flux curve at $\sim 4$ and $\sim 14$ h reflect safetyrelated overnight system shutdowns.

The anticipated mass reduction of 50\% was achieved within $22 \mathrm{~h}$ after supplying $3 \mathrm{~kg}$ of feed. The flux decline from $\sim 15$ to $\sim 7 \mathrm{~L} / \mathrm{m}^{2} / \mathrm{h} /$ bar probably reflected two effects: fouling on the membrane surface and/or membrane pores and a concentration-related increase in viscosity. The characteristics of these effects will be investigated in further studies to determine their individual contributions to filtration performance. The retention of the residual lignosulfonate fraction was calculated based on size-exclusion chromatography (SEC) analytics. The molecular weight distributions in the feed, retentate after $22 \mathrm{~h}$ and permeate after $22 \mathrm{~h}$ are compared in Figure 9.

The characteristics of the illustrated molecular weight distribution curves are summarized in Table 3. The presentation of the curves and the associated data indicate that a notable fraction of partially degraded or non-degraded lignosulfonate is retained by the $30-\mathrm{nm}$ membrane. The number average molar mass $\left(M_{n}\right)$ and the mass average molar mass $\left(M_{w}\right)$ of the permeate were lower than those of the feed and retentate. The polydispersity index (PDI), which represents the width of a molecular weight distribution, was also significantly lower in the permeate than in the feed and retentate.

The retention of lignosulfonate fractions much smaller than the MWCO of the membrane $(800 \mathrm{kDa})$ may reflect the filtration effects of a fouling layer. Further investigations will 


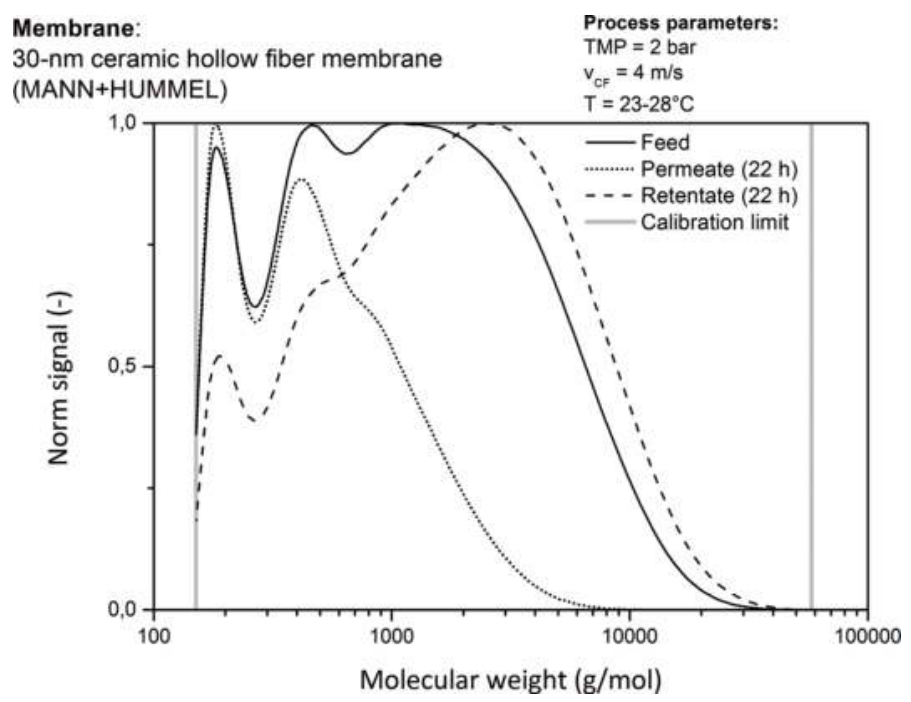

Figure 9. Molecular weight distribution of feed, retentate and permeate $\left(\mathrm{TMP}=2 \mathrm{bar}, \mathrm{v}_{\mathrm{CF}}=4 \mathrm{~m} / \mathrm{s}, \mathrm{T}=23-28^{\circ} \mathrm{C}, 30-\mathrm{nm}\right.$ ceramic hollow fiber membrane (MANN + HUMMEL)).

\begin{tabular}{llcc}
\hline Sample name & $\mathbf{M}_{\mathbf{n}}(\mathrm{g} / \mathrm{mol})$ & $\mathbf{M}_{\mathbf{w}}(\mathrm{g} / \mathrm{mol})$ & PDI (-) \\
\hline Feed & 457 & 1768 & 3.87 \\
Permeate (22 h) & 305 & 559 & 1.83 \\
Retentate (22 h) & 614 & 2665 & 4.34 \\
\hline
\end{tabular}

Table 3. Characteristics of the presented molecular weight distributions.

characterize the fouling effects observed with this setup and a potential retention of products such as vanillin and syringaldehyde.

\subsubsection{Conclusion and outlook}

Thermochemical lignin degradation has been investigated extensively, and each thermochemical degradation process generates characteristic degradation products. Hydrogenolysis creates simple phenolic products with low functionality, suitable as bulk chemicals, whereas oxidative conversion generates products with increased functionality, suitable for the production of aromatic aldehydes (e.g., vanillin). Lignin degradation is followed by the purification of the reaction mixtures, including the removal of residual partially degraded or non-degraded lignin which can be recycled into the reaction to improve lignin conversion rates and total process efficiency. However, the operability of the degradation process may be restricted by such recycling.

As we have shown, membrane filtration systems are suitable as a separation technology for the retention of partially degraded or non-degraded lignin fractions. Further research will characterize the fouling effects and will help to optimize filtration performance. It is clear that filtration 
efficiency depends on the feed characteristics, and our data presented herein are therefore relevant only for processes featuring the oxidative degradation of lignosulfonate with methanol as the solvent. Other lignin sources, degradation methods, solvents and catalysts are likely to influence the filtration performance, and membrane filtration processes must therefore be designed on a case-by-case basis. Intensive research to create a database covering all process parameters (particularly the lignin source, solvent and type of degradation process) could reduce the preliminary effort required to design optimal membrane-based filtration processes.

\section{Acknowledgements}

We acknowledge Dr Richard M. Twyman for editing the manuscript, MANN + HUMMEL $\mathrm{GmbH}$ for supplying the ceramic membranes and Sappi Europe, Stockstadt Mill, Germany and CMBlu Projekt AG, Alzenau, Germany for supplying the feed solutions. This work has been financed by Fachagentur für nachwachsende Rohstoffe e.v. (FNR) through funds of Bundeministeriums für Ernährung und Landwirtschaft (BMEL) out of the special asset "Energieund Klimafonds" by a resolution of Deutscher Bundestag (FKZ: 22402816).

\section{Author details}

Stefan Schoenherr ${ }^{1}$, Mehrdad Ebrahimi $^{1}$ and Peter Czermak $^{1,2,3 *}$

*Address all correspondence to: peter.czermak@kmub.thm.de

1 Institute of Bioprocess Engineering and Pharmaceutical Technology, University of Applied Sciences Mittelhessen, Giessen, Germany

2 Department of Chemical Engineering, Kansas State University, Manhattan, KS, USA

3 Faculty of Biology and Chemistry, Justus-Liebig University of Giessen, Germany

\section{References}

[1] Sun Y, Cheng J. Hydrolysis of lignocellulosic materials for ethanol production: A review. Bioresource Technology. 2002;83(1):1-11. DOI: https://doi.org/10.1016/S0960-8524(01) 00212-7

[2] Zakzeski J, Bruijnincx PCA, Jongerius AL, Weckhuysen BM. The catalytic valorization of lignin for the production of renewable chemicals. Chemical Reviews. 2010;110(6):35523599. DOI: https://doi.org/10.1021/cr900354u 20218547

[3] Kirk TK, Farrell RL. Enzymatic "combustion": The microbial degradation of lignin. Annual Review of Microbiology. 1987;41:465-505. DOI: https://doi.org/10.1146/annurev. mi.41.100187.0023413318677 
[4] Hammel KE. Fungal degradation of lignin. In: Cadisch G, editor. Driven by Nature: Plant Litter Quality and Decomposition. Wallingford: CAB International. 1997;33-45

[5] Pandey MP, Kim CS. Lignin depolymerization and conversion: A review of thermochemical methods. Chemical Engineering and Technology. 2011;34(1):29-41. DOI: https:// doi.org/10.1002/ceat.201000270

[6] Vanholme R, Demedts B, Morreel K, Ralph J, Boerjan W. Lignin biosynthesis and structure. Plant Physiology. 2010;153(3):895-905. DOI: https://doi.org/10.1104/pp.110.155119 20472751

[7] Faix O. Classification of lignins from different botanical origins by FT-IR spectroscopy. Holzforschung. 1991;45(s1):21-28. DOI: https://doi.org/10.1515/hfsg.1991.45.s1.21

[8] Pinto PC, Evtuguin DV, Neto CP. Effect of structural features of wood biopolymers on hardwood pulping and bleaching performance. Industrial and Engineering Chemistry Research. 2005;44(26):9777-9784. DOI: https://doi.org/10.1021/ie050760o

[9] Evtuguin DV, Neto CP, Silva AMS, et al. Comprehensive study on the chemical structure of dioxane lignin from plantation Eucalyptus globulus wood. Journal of Agricultural and Food Chemistry. 2001;49(9):4252-4261. DOI: https://doi.org/10.1021/jf010315d

[10] Calvo-Flores FG, Dobado JA. Lignin as renewable raw material. ChemSusChem. 2010; 3(11):1227-1235. DOI: https://doi.org/10.1002/cssc.201000157 20839280

[11] Gonzalo G, de Colpa DI, Habib MHM, Fraaije MW. Bacterial enzymes involved in lignin degradation. Journal of Biotechnology 2016;236:110-119. DOI: https://doi.org/10.1016/j. jbiotec.2016.08.011. PMID: 27544286

[12] Faulon J-L, Hatcher PG. Is there any order in the structure of lignin? Energy \& Fuels. 1994;8(2):402-407. DOI: https://doi.org/10.1021/ef00044a018

[13] Rodrigues Pinto PC, Borges da Silva EA, Rodrigues AE. Insights into oxidative conversion of lignin to high-added-value phenolic aldehydes. Industrial and Engineering Chemistry Research. 2011;50(2):741-748. DOI: https://doi.org/10.1021/ie102132a

[14] Awungacha Lekelefac C, Busse N, Herrenbauer M, Czermak P. Photocatalytic based degradation processes of lignin derivatives. International Journal of Photoenergy. 2015;2015(12):1-18. DOI: https://doi.org/10.1155/2015/137634

[15] Busch R, Hirth T, Liese A, et al. Nutzung nachwachsender Rohstoffe in der industriellen Stoffproduktion. Chemie Ingenieur Technik. 2006;78(3):219-228. DOI: https://doi.org/ 10.1002/cite.200500178

[16] Gustavsson L, Haus S, Lundblad M, et al. Climate change effects of forestry and substitution of carbon-intensive materials and fossil fuels. Renewable and Sustainable Energy Reviews. 2017;67:612-624. DOI: https://doi.org/10.1016/j.rser.2016.09.056

[17] Allison EH, Perry AL, Badjeck M-C, et al. Vulnerability of national economies to the impacts of climate change on fisheries. Fish and Fisheries. 2009;10(2):173-196. DOI: https://doi.org/10.1111/j.1467-2979.2008.00310.x 
[18] Quadrelli R, Peterson S. The energy-climate challenge: Recent trends in $\mathrm{CO}_{2}$ emissions from fuel combustion. Energy Policy. 2007;35(11):5938-5952. DOI: https://doi.org/10.1016/j. enpol.2007.07.001

[19] Bugg TDH, Rahmanpour R. Enzymatic conversion of lignin into renewable chemicals. Current Opinion in Chemical Biology. 2015;29:10-17. https://doi.org/10.1016/j.cbpa.2015. 06.009 PMID: 26121945

[20] Saxena RC, Adhikari DK, Goyal HB. Biomass-based energy fuel through biochemical routes: A review. Renewable and Sustainable Energy Reviews. 2009;13(1):167-178. DOI: https://doi.org/10.1016/j.rser.2007.07.011

[21] Hileman JI, Donohoo PE, Stratton RW. Energy content and alternative jet fuel viability. Journal of Propulsion and Power. 2010;26(6):1184-1196. DOI: https://doi.org/10.2514/ 1.46232

[22] Mathews SL, Grunden AM, Pawlak J. Degradation of lignocellulose and lignin by Paenibacillus glucanolyticus. International Biodeterioration \& Biodegradation. 2016;110: 79-86. DOI: https://doi.org/10.1016/j.ibiod.2016.02.012

[23] Kamm B, Kamm M. Principles of biorefineries. Applied Microbiology and Biotechnology. 2004;64(2):137-145. DOI: https://doi.org/10.1007/s00253-003-1537-7 14749903

[24] Strassberger Z, Tanase S, Rothenberg G. The pros and cons of lignin valorisation in an integrated biorefinery. RSC Advances. 2014;4(48):25310-25318. DOI: https://doi.org/10. 1039/C4RA04747H

[25] JE Holladay, JF White, JJ Bozell, and D Johnson. Top Value-Added Chemicals from Biomass Volume II - Results of Screening for Potential Candidates from Biorefinery Lignin. Prepared for the U.S. Department of Energy under Contract DE-AC05-76RL01830; 2007

[26] Gosselink R, Jong E. De, Guran B, Abächerli a. Co-ordination network for ligninStandardisation, production and applications adapted to market requirements (EUROLIGNIN). Industrial Crops and Products. 2004;20(2):121-129. DOI: https://doi. org/10.1016/j.indcrop.2004.04.015

[27] Silva EB, Zabkova M, Araújo JD, et al. An integrated process to produce vanillin and lignin-based polyurethanes from Kraft lignin. Chemical Engineering Research and Design. 2009;87(9):1276-1292. DOI: https://doi.org/10.1016/j.cherd.2009.05.008

[28] Kuhad RC, Gupta R, Singh A. Microbial cellulases and their industrial applications. Enzyme Research. 2011;2011:280696. DOI: https://doi.org/10.4061/2011/280696. PMID: 21912738

[29] Saha BC. Hemicellulose bioconversion. Journal of Industrial Microbiology \& Biotechnology. 2003;30(5):279-291. DOI: https://doi.org/10.1007/s10295-003-0049-x 12698321

[30] Leonowicz A, Matuszewska A, Luterek J, et al. Biodegradation of lignin by white rot fungi. Fungal Genet Biol. 1999;27(2-3):175-185. [https://doi.org/10.1006/fgbi.1999.1150] [PMID: 10441443] 
[31] Sánchez C. Lignocellulosic residues: Biodegradation and bioconversion by fungi. Biotechnology Advances. 2009;27(2):185-194. DOI: https://doi.org/10.1016/j.biotechadv.2008.11. 00119100826

[32] Timell TE, Eriksson K-EL, Blanchette RA, Ander P. Microbial and Enzymatic Degradation of Wood and Wood Components. Berlin, Heidelberg: Springer; 1990

[33] Cowling EB. Comparative biochemistry of decay of sweetgum sapwood by white-rot and brown-rot fungi. USDA Technical Bulletin; 1961

[34] Wong DWS. Structure and action mechanism of ligninolytic enzymes. Applied Biochemistry and Biotechnology. 2009;157(2):174-209. DOI: https://doi.org/10.1007/s12010008-8279-z 18581264

[35] Tuor U, Winterhalter K, Fiechter A. Enzymes of white-rot fungi involved in lignin degradation and ecological determinants for wood decay. Journal of Biotechnology. 1995;41(1): 1-17. DOI: https://doi.org/10.1016/0168-1656(95)00042-O

[36] Monrroy M, Ortega I, Ramírez M, Baeza J, Freer J. Structural change in wood by brown rot fungi and effect on enzymatic hydrolysis. Enzyme and Microbial Technology. 2011;49(5):472-477. DOI: https://doi.org/10.1016/j.enzmictec.2011.08.004 22112620

[37] Jensen KA, Houtman CJ, Ryan ZC, Hammel KE. Pathways for extracellular Fenton chemistry in the brown rot basidiomycete Gloeophyllum trabeum. Applied and Environmental Microbiology. 2001;67(6):2705-2711. DOI: https://doi.org/10.1128/AEM.67.6. 2705-2711.2001 11375184

[38] Green F, Highley TL. Mechanism of brown-rot decay: Paradigm or paradox. International Biodeterioration \& Biodegradation. 1997;39(2-3):113-124. DOI: https://doi.org/ 10.1016/S0964-8305(96)00063-7

[39] Dashtban M, Schraft H, Syed TA, Qin W. Fungal biodegradation and enzymatic modification of lignin. International Journal of Biochemistry and Molecular Biology. 2010;1(1): 36-50

[40] Findlay WPK, Savory JG. Breakdown of timber in water cooling towers. 7th International Botanical Congress, Stockholm; 1950. p. 1

[41] Levy J. The soft rot fungi: Their mode of action and significance in the degradation of wood. In: Advances in Botanical Research. Vol. 2. Elsevier; 1966. pp. 323-357

[42] Floudas D, Binder M, Riley R, et al. The Paleozoic origin of enzymatic lignin decomposition reconstructed from 31 fungal genomes. Science. 2012;336(6089):1715-1719. DOI: https://doi.org/10.1126/science.1221748 22745431

[43] Butler MJ, Day AW. Destruction of fungal melanins by ligninases of Phanerochaete chrysosporium and other white rot fungi. International Journal of Plant Sciences. 1998;159(6): 989-995. DOI: https://doi.org/10.1086/314093 
[44] Sugano Y. DyP-type peroxidases comprise a novel heme peroxidase family. Cellular and Molecular Life Sciences. 2009;66(8):1387-1403. DOI: https://doi.org/10.1007/s00018-0088651-8 19099183

[45] Abdel-Hamid AM, Solbiati JO, Cann IKO. Insights into lignin degradation and its potential industrial applications. Advances in Applied Microbiology. 2013;82:1-28. DOI: https://doi.org/10.1016/B978-0-12-407679-2.00001-6 23415151

[46] Guillen F, AT M, MMJ. Substrate specificity and properties of the aryl-alcohol oxidase from the ligninolytic fungus Pleurotus eryngii. European Journal of Biochemistry. 1992;209(2):603-611. DOI: https://doi.org/10.1111/j.1432-1033.1992.tb17326.x

[47] Kersten PJ. Glyoxal oxidase of Phanerochaete chrysosporium its characterization and activation by lignin peroxidase. Proceedings of the National Academy of Sciences. USA 1990;(87):2936-2940

[48] Gutiérrez A, Caramelo L, Prieto A, Martínez MJ, Martínez AT. Anisaldehyde production and aryl-alcohol oxidase and dehydrogenase activities in ligninolytic fungi of the genus Pleurotus. Applied and Environmental Microbiology 1994;60(6):1783-1788. [PMID: 8031078]

[49] Guillén F, Martínez MJ, Muñoz C, Martínez AT. Quinone redox cycling in the ligninolytic fungus Pleurotus eryngii leading to extracellular production of superoxide anion radical. Archives of Biochemistry and Biophysics. 1997;339(1):190-199. DOI: https:/doi.org/ 10.1006/abbi.1996.98349056249

[50] Henriksson G, Johansson G, Pettersson G. A critical review of cellobiose dehydrogenases. Journal of Biotechnology. 2000;78(2):93-113. DOI: https://doi.org/10.1016/S01681656(00)00206-6

[51] Thurston CF. The structure and function of fungal laccases. Microbiology. 1994;140(1): 19-26. DOI: https://doi.org/10.1099/13500872-140-1-19

[52] Hofrichter M. Review: Lignin conversion by manganese peroxidase (MnP). Enzyme and Microbial Technology. 2002;30(4):454-466. DOI: https://doi.org/10.1016/S0141-0229(01) 00528-2

[53] Martínez ÁT, Speranza M, Ruiz-Dueñas FJ, Ferreira P, Camarero S, Guillén F, Martínez MJ, Gutiérrez A. Biodegradation of lignocellulosics: Microbial, chemical, and enzymatic aspects of the fungal attack of lignin. International Microbiology. 2005;8:195-204

[54] Claus H. Laccases: Structure, reactions, distribution. Micron. 2004;35(1-2):93-96. DOI: https://doi.org/10.1016/j.micron.2003.10.029 15036303

[55] Bourbonnais R, Paice MG. Oxidation of non-phenolic substrates. FEBS Letters. 1990;267(1): 99-102. DOI: https://doi.org/10.1016/0014-5793(90)80298-W

[56] Kawai S, Nakagawa M, Ohashi H. Degradation mechanisms of a nonphenolic $\beta-\mathrm{O}-4$ lignin model dimer by Trametes versicolor laccase in the presence of 1-hydroxybenzotriazole. Enzyme and Microbial Technology. 2002;30(4):482-489. DOI: https:/doi.org/ 10.1016/S0141-0229(01)00523-3 
[57] Dedhia BS, Vetal MD, Rathod VK, Levente C. Xylanase and laccase aided bio-bleaching of wheat straw pulp. Canadian Journal of Chemical Engineering. 2014;92(1):131-138. DOI: https://doi.org/10.1002/cjce.21798

[58] María E. Eugenio, Manuel Hrenández, Raquel Moya, Raquel Martín-Sampedro, Juan C. Villar, Arias ME. Evaluation of a new laccase produced by Streptomyces ipomoea on biobleaching and ageing of kraft pulps. BioResources Aug 2011;6(3):3231-3241

[59] Valli K, Wariishi H, Gold MH. Oxidation of monomethoxylated aromatic compounds by lignin peroxidase: Role of veratryl alcohol in lignin biodegradation. Biochemistry. 2002;29(37):8535-8539. DOI: https://doi.org/10.1021/bi00489a005

[60] Lundell T, Wever R, Floris R, et al. Lignin peroxidase L3 from Phlebia rediata. Pre-steadystate and steady-state studies with veratryl alcohol and a non-phenolic lignin model compound 1-(3,4-dimethoxyphenyl)-2-(2-methoxyphenoxy)propane-1,3-diol. European Journal of Biochemistry. 1993;211(3):391-4020. DOI: https://doi.org/10.1111/j.14321033.1993.tb17562.x

[61] Miki K, Renganathan V, Gold MH. Mechanism of beta-aryl ether dimeric lignin model compound oxidation by lignin peroxidase by Phanerochaete chrysosporium. Biochemistry. 2002;25(17):4790-4796. DOI: https://doi.org/10.1021/bi00365a011

[62] Hammel KE, Moen MA. Depolymerization of a synthetic lignin in vitro by lignin peroxidase. Enzyme and Microbial Technology. 1991;13(1):15-18. DOI: https:/doi.org/ 10.1016/0141-0229(91)90182-A

[63] Reddy GVB, Sridhar M, Gold MH. Cleavage of nonphenolic beta-1 diarylpropane lignin model dimers by manganese peroxidase from Phanerochaete chrysosporium. Evidence for a hydrogen abstraction mechanism. European Journal of Biochemistry. 2003;270(2):284292. DOI: https://doi.org/10.1046/j.1432-1033.2003.03386.x

[64] Ruiz-Dueñas FJ, Camarero S, Pérez-Boada M, Martínez MJ, Martínez ATA. New versatile peroxidase from Pleurotus. Biochemical Society Transactions. 2001;29(2):116-122. DOI: https://doi.org/10.1042/bst0290116

[65] Camarero S, Sarkar S, Ruiz-Dueñas FJ, Martínez MJ, Martínez ÁT. Description of a versatile peroxidase involved in the natural degradation of lignin that has both manganese peroxidase and lignin peroxidase substrate interaction sites. The Journal of Biological Chemistry. 1999;274(15):10324-10330. DOI: https://doi.org/10.1074/jbc.274.15.10324

[66] Liers C, Bobeth C, Pecyna M, Ullrich R, Hofrichter M. DyP-like peroxidases of the jelly fungus Auricularia auricula-judae oxidize nonphenolic lignin model compounds and high-redox potential dyes. Applied Microbiology and Biotechnology. 2010;85(6):18691879. DOI: https://doi.org/10.1007/s00253-009-2173-7 19756587

[67] Colpa DI, Fraaije MW, van Bloois E. DyP-type peroxidases: A promising and versatile class of enzymes. Journal of Industrial Microbiology \& Biotechnology. 2014;41(1):1-7. DOI: https://doi.org/10.1007/s10295-013-1371-6. PMID: 24212472 
[68] Kim SJ, Shoda M. Purification and characterization of a novel peroxidase from Geotrichum candidum dec 1 involved in decolorization of dyes. Applied and Environmental Microbiology. 1999;65(3):1029-1035. [PMID: 10049859]

[69] Adav SS, Ng CS, Arulmani M, Sze SK. Quantitative iTRAQ secretome analysis of cellulolytic Thermobifida fusca. Journal of Proteome Research. 2010;9(6):3016-3024. DOI: https://doi.org/10.1021/pr901174z 20408570

[70] Vicuña R. Bacterial degradation of lignin. Enzyme and Microbial Technology. 1988;10(11): 646-655. DOI: https://doi.org/10.1016/0141-0229(88)90055-5

[71] Zimmermann W. Degradation of lignin by bacteria. Journal of Biotechnology. 1990;13 (2-3): 119-130. DOI: https://doi.org/10.1016/0168-1656(90)90098-V

[72] Liese W, editor. Biological Transformation of Wood by Microorganisms. Berlin, Heidelberg: Springer; 1975

[73] Davis JR, Goodwin L, Teshima H, et al. Genome sequence of Streptomyces viridosporus strain T7A ATCC 39115, a lignin-degrading actinomycete. Genome Announcements. 2013;1(4). DOI: https://doi.org/10.1128/genomeA.00416-13 23833133

[74] Brown ME, Walker MC, Nakashige TG, Iavarone AT, Chang MCY. Discovery and characterization of heme enzymes from unsequenced bacteria: Application to microbial lignin degradation. Journal of the American Chemical Society. 2011;133(45):18006-18009. DOI: https://doi.org/10.1021/ja203972q 21671563

[75] Bugg TDH, Ahmad M, Hardiman EM, Singh R. The emerging role for bacteria in lignin degradation and bio-product formation. Current Opinion in Biotechnology. 2011;22(3): 394-400. DOI: https://doi.org/10.1016/j.copbio.2010.10.009 21071202

[76] Sharma P, Goel R, Capalash N. Bacterial laccases. World Journal of Microbiology and Biotechnology. 2007;23(6):823-832. DOI: https://doi.org/10.1007/s11274-006-9305-3

[77] Ahmad M, Roberts JN, Hardiman EM, Singh R, Eltis LD, Bugg TDH. Identification of DypB from Rhodococcus jostii RHA1 as a lignin peroxidase. Biochemistry. 2011;50(23): 5096-5107. DOI: https://doi.org/10.1021/bi101892z 21534568

[78] Kellner H, Luis P, Zimdars B, Kiesel B, Buscot F. Diversity of bacterial laccase-like multicopper oxidase genes in forest and grassland Cambisol soil samples. Soil Biology and Biochemistry. 2008;40(3):638-648. DOI: https://doi.org/10.1016/j.soilbio.2007.09.013

[79] Alexandre G, Zhulin IB. Laccases are widespread in bacteria. Trends in Biotechnology. 2000;18(2):41-42. DOI: https://doi.org/10.1016/S0167-7799(99)01406-7

[80] Fernandes TAR, Silveira WBd, Passos FML, Zucchi TD. Laccases from actinobacteriaWhat we have and what to expect. Archives of Iranian Medicine. 2014;04(06):285-296. DOI: https://doi.org/10.4236/aim.2014.46035

[81] Lambertz C, Ece S, Fischer R, Commandeur U. Progress and obstacles in the production and application of recombinant lignin-degrading peroxidases. Bioengineered. 2016;7(3): 145-154. DOI: https://doi.org/10.1080/21655979.2016.1191705 27295524 
[82] Ihssen J, Reiss R, Luchsinger R, Thöny-Meyer L, Richter M. Biochemical properties and yields of diverse bacterial laccase-like multicopper oxidases expressed in Escherichia coli. Scientific Reports. 2015;5:10465. DOI: https://doi.org/10.1038/srep10465 26068013

[83] Sainsbury PD, Hardiman EM, Ahmad M, et al. Breaking down lignin to high-value chemicals: The conversion of lignocellulose to vanillin in a gene deletion mutant of Rhodococcus jostii RHA1. ACS Chemical Biology. 2013;8(10):2151-2156. DOI: https://doi. org/10.1021/cb400505a 23898824

[84] Giles RL, Zackeru JC, Elliott GD, Parrow MW. Fungal growth necessary but not sufficient for effective biopulping of wood for lignocellulosic ethanol applications. International Biodeterioration \& Biodegradation. 2012;67:1-7. DOI: https://doi.org/10.1016/j.ibiod.2011. 11.007

[85] Eriksson K-E. Biotechnology in the pulp and paper industry. Wood Science and Technology 1990;24(1):79-101. [https://doi.org/10.1007/BF00225309]

[86] Akhtar M, Scott GM, Aziz A, Lentz MJ, Horn EG, Inventors. Biopulping Industrial Wood Waste. US 6,402,887 B1. Nov 30, 1998

[87] Singh P, Sulaiman O, Hashim R, Rupani PF, Peng LC. Biopulping of lignocellulosic material using different fungal species: A review. Reviews in Environmental Science and Biotechnology. 2010;9(2):141-151. DOI: https://doi.org/10.1007/s11157-010-9200-0

[88] Breen A, Singleton FL. Fungi in lignocellulose breakdown and biopulping. Current Opinion in Biotechnology. 1999;10(3):252-258. DOI: https://doi.org/10.1016/S0958-1669(99)80044-5

[89] Ferraz A, Guerra A, Mendonça R, et al. Technological advances and mechanistic basis for fungal biopulping. Enzyme and Microbial Technology. 2008;43(2):178-185. DOI: https://doi.org/10.1016/j.enzmictec.2007.10.002

[90] Arias ME, Arenas M, Rodriguez J, Soliveri J, Ball AS, Hernandez M. Kraft pulp biobleaching and mediated oxidation of a nonphenolic substrate by Laccase from Streptomyces cyaneus CECT 3335. Applied and Environmental Microbiology. 2003;69(4):19531958. DOI: https://doi.org/10.1128/AEM.69.4.1953-1958.2003

[91] Busse N, Kraume M, Czermak P. Modeling the design and operational mode of a continuous membrane reactor for enzymatic lignin modification. Biochemical Engineering Journal. 2017;124:88-98. DOI: https://doi.org/10.1016/j.bej.2017.04.007

[92] Busse N, Fuchs F, Kraume M, Czermak P. Treatment of enzyme-initiated delignification reaction mixtures with ceramic ultrafiltration membranes: Experimental investigations and modeling approach. Separation Science and Technology. 2016;76(3):1-20. DOI: https://doi.org/10.1080/01496395.2016.1167739

[93] Taboada-Puig R, Lu-Chau TA, Eibes G, Feijoo G, Moreira MT, Lema JM. Continuous removal of endocrine disruptors by versatile peroxidase using a two-stage system. Biotechnology Progress. 2015;31(4):908-916. DOI: https://doi.org/10.1002/btpr.2116 26033915 
[94] Méndez-Hernández JE, Eibes G, Arca-Ramos A, et al. Continuous removal of nonylphenol by versatile peroxidase in a two-stage membrane bioreactor. Applied Biochemistry and Biotechnology. 2015;175(6):3038-3047. DOI: https://doi.org/10.1007/s12010-014-1474-1 255 88527

[95] Busse N. Reaction kinetics of versatile peroxidase for the degradation of lignin compounds. American Journal of Biochemistry and Biotechnology 2013;9(4):365-394. DOI: https://doi.org/10.3844/ajbbsp.2013.365.394

[96] Busse N, Kraume M, Czermak P. Optimal permeate flux for an enzymatic oxidation of technical lignins in a membrane reactor. Separation Science and Technology. 2016;52(2): 374-380. DOI: https://doi.org/10.1080/01496395.2016.1213748

[97] Peña N, Gallego S, del Vigo F, Chesters SP. Evaluating impact of fouling on reverse osmosis membranes performance. Desalination and Water Treatment. 2013;51(4-6): 958-968. DOI: https://doi.org/10.1080/19443994.2012.699509

[98] Ebrahimi M, Busse N, Kerker S, Schmitz O, Hilpert M, Czermak P. Treatment of the bleaching effluent from sulfite pulp production by ceramic membrane filtration. Membranes (Basel). 2015;6(1). DOI: https://doi.org/10.3390/membranes6010007 26729180

[99] Arkell A, Olsson J, Wallberg O. Process performance in lignin separation from softwood black liquor by membrane filtration. Chemical Engineering Research and Design. 2014;92(9):1792-1800. DOI: https://doi.org/10.1016/j.cherd.2013.12.018

[100] Ebrahimi M, Kerker S, Daume S, et al. Innovative ceramic hollow fiber membranes for recycling/reuse of oilfield produced water. Desalination and Water Treatment. 2014;55(13): 3554-3567. DOI: https://doi.org/10.1080/19443994.2014.947780

[101] Gupta VK. Microbial Enzymes in Bioconversions of Biomass. Cham: Springer International Publishing; 2016

[102] Ayala M, Pickard MA, Vazquez-Duhalt R. Fungal enzymes for environmental purposes, a molecular biology challenge. Journal of Molecular Microbiology and Biotechnology. 2008;15(2-3):172-180. DOI: https://doi.org/10.1159/000121328 18685269

[103] Casella L, Monzani E, Nicolis S. Potential applications of peroxidases in the fine chemical industries. In: Torres E, Ayala M, editors. Biocatalysis Based on Heme Peroxidases: Peroxidases as Potential Industrial Biocatalysts. Berlin, Heidelberg: Imprint Springer; 2010. pp. 111-153

[104] Conesa A, van den Hondel CAMJJ, Punt PJ. Studies on the production of fungal peroxidases in Aspergillus niger. Applied and Environmental Microbiology. 2000;66(7):30163023. DOI: https://doi.org/10.1128/AEM.66.7.3016-3023.2000

[105] de Weert S, Lokman BC. Heterologous expression of peroxidases. In: Torres E, Ayala M, editors. Biocatalysis Based on Heme Peroxidases: Peroxidases as Potential Industrial Biocatalysts. Berlin, Heidelberg: Imprint Springer; 2010. pp. 315-333 
[106] Andreozzi R. Advanced oxidation processes (AOP) for water purification and recovery. Catalysis Today. 1999;53(1):51-59. DOI: https://doi.org/10.1016/S0920-5861(99)00102-9

[107] Ross F, Ross AB. Selected Specific Rates of Reactions of Transients from Water in Aqueous Solution. Gaithersburg, MD: National Bureau of Standards; 1977

[108] Hoigné J, Bader H. Rate constants of reactions of ozone with organic and inorganic compounds in water-II. Water Research. 1983;17(2):185-194. DOI: https:/doi.org/ 10.1016/0043-1354(83)90099-4

[109] Linsebigler AL, Lu G, Yates JT. Photocatalysis on $\mathrm{TiO}_{2}$ surfaces: Principles, mechanisms, and selected results. Chemical Reviews. 1995;95(3):735-758. DOI: https://doi.org/10.1021/ cr00035a013

[110] Nosaka Y, Fox MA. Kinetics for electron transfer from laser-pulse irradiated colloidal semiconductors to adsorbed methylviologen: Dependence of the quantum yield on incident pulse width. The Journal of Physical Chemistry. 1988;92(7):1893-1897. DOI: https://doi.org/10.1021/j100318a039

[111] Rajeshwar K. Photoelectrochemistry and the environment. Journal of Applied Electrochemistry. 1995;25(12):1067-1082. [https://doi.org/10.1007/BF00242533]

[112] Hashimoto K, Irie $\mathrm{H}$, Fujishima $\mathrm{A}$. $\mathrm{TiO}_{2}$ Photocatalysis: A historical overview and future prospects. Japanese Journal of Applied Physics. 2005;44(12):8269-8285. DOI: https://doi. org/10.1143/JJAP.44.8269

[113] Fujishima A, Zhang X, Tryk D. $\mathrm{TiO}_{2}$ photocatalysis and related surface phenomena. Surface Science Reports. 2008;63(12):515-582. DOI: https://doi.org/10.1016/j.surfrep.2008. 10.001

[114] Tang H, Prasad K, Sanjinès R, Schmid PE, Lévy F. Electrical and optical properties of $\mathrm{TiO}_{2}$ anatase thin films. Journal of Applied Physics. 1994;75(4):2042-2047. DOI: https:// doi.org/10.1063/1.356306

[115] Lekelefac CA, Czermak P. Degradation of lignin derivatives by Photocatalysts. In: Cao W, editor. Semiconductor Photocatalysis - Materials, Mechanisms and Applications. Rijeka, Croatia: InTech; 2016

[116] Kansal SK, Singh M, Sud D. Studies on $\mathrm{TiO}(2) / \mathrm{ZnO}$ photocatalysed degradation of lignin. Journal of Hazardous Materials. 2008;153(1-2):412-417. DOI: https://doi.org/ 10.1016/j.jhazmat.2007.08.091 17936502

[117] Ohnishi H, Matsumura M, Tsubomura H, Iwasaki M. Bleaching of lignin solution by a photocatalyzed reaction on semiconductor photocatalysts. Industrial and Engineering Chemistry Research. 1989;28(6):719-724. DOI: https://doi.org/10.1021/ie00090a012

[118] Serpone N. Relative photonic efficiencies and quantum yields in heterogeneous Photocatalysis. Journal of Advanced Oxidation Technologies. 1997;2(1):1-12. [https:// doi.org/10.1515/jaots-1997-0104] 
[119] Hoffmann MR, Martin ST, Choi W, Bahnemann DW. Environmental applications of semiconductor photocatalysis. Chemical Reviews. 1995;95(1):69-96. DOI: https:/doi. org/10.1021/cr00033a004

[120] Rothenberger G, Moser J, Graetzel M, Serpone N, Sharma DK. Charge carrier trapping and recombination dynamics in small semiconductor particles. Journal of the American Chemical Society. 1985;107(26):8054-8059. DOI: https://doi.org/10.1021/ja00312a043

[121] Kobayakawa K, Sato Y, Nakamura S, Fujishima A. Photodecomposition of kraft lignin catalyzed by titanium dioxide. Bulletin of the Chemical Society of Japan. 1989;62(11):34333436. DOI: https://doi.org/10.1246/bcsj.62.3433

[122] Cristina Yeber M, Rodríguez J, Freer J, Durán ND, Mansilla H. Photocatalytic degradation of cellulose bleaching effluent by supported $\mathrm{TiO}_{2}$ and $\mathrm{ZnO}$. Chemosphere 2000;41(8): 1193-1197. DOI: https://doi.org/10.1016/S0045-6535(99)00551-2

[123] Peralta-Zamora P, de Moraes SG Pelegrini R, et al. Evaluation of $\mathrm{ZnO}, \mathrm{TiO}_{2}$ and supported $\mathrm{ZnO}$ on the photoassisted remediation of black liquor, cellulose and textile mill effluents. Chemosphere. 1998;36(9):2119-2133. DOI: https://doi.org/10.1016/S00456535(97)10074-1

[124] Stephen Davidson R, Dunn LA, Castellan A, Nourmamode A. A study of the photobleaching and photoyellowing of paper containing lignin using fluorescence spectroscopy. Journal of Photochemistry and Photobiology A: Chemistry. 1991;58(3):349-359. DOI: https://doi.org/10.1016/1010-6030(91)87054-Y

[125] Gierer J. Formation and involvement of superoxide $\left(\mathrm{O}_{2} / \mathrm{HO}_{2}\right)$ and hydroxyl $(\mathrm{OH} \cdot)$ radicals in TCF bleaching processes: A review. Holzforschung. 1997;51(1):34-46. DOI: https://doi.org/10.1515/hfsg.1997.51.1.34

[126] Catalkaya EC, Kargi F. Color, TOC and AOX removals from pulp mill effluent by advanced oxidation processes: A comparative study. Journal of Hazardous Materials. 2007;139(2):244-253. DOI: https://doi.org/10.1016/j.jhazmat.2006.06.023 16839682

[127] Jokela JK, Laine M, Ek M, Salkinoja-Salonen M. Effect of biological treatment on halogenated organics in bleached kraft pulp mill effluents studied by molecular weight distribution analysis. Environmental Science \& Technology. 1993;27(3):547-557. DOI: https:// doi.org/10.1021/es00040a014

[128] Balcioglu I, Arslan I. Application of photocatalytic oxidation treatment to pretreated and raw effluents from the Kraft bleaching process and textile industry. Environmental Pollution. 1998;103(2-3):261-268. DOI: https://doi.org/10.1016/S0269-7491(98) 00112-2

[129] Tanaka K, Calanag R, Hisanaga T. Photocatalyzed degradation of lignin on $\mathrm{TiO}_{2}$. Journal of Molecular Catalysis A: Chemical. 1999;138(2-3):287-294. DOI: https://doi.org/ 10.1016/S1381-1169(98)00161-7 
[130] Turchi CS, Ollis DF. Comment. photocatalytic reactor design: An example of masstransfer limitations with an immobilized catalyst. The Journal of Physical Chemistry. 1988;92(23):6852-6853. DOI: https://doi.org/10.1021/j100334a070

[131] Awungacha Lekelefac C, Czermak P, Herrenbauer M. Evaluation of Photocatalytic active coatings on sintered glass tubes by methylene blue. International Journal of Photoenergy. 2013;2013(4):1-9. DOI: https://doi.org/10.1155/2013/614567

[132] Miyata Y, Miyazaki K, Miura M, Shimotori Y, Aoyama M, Nakatani H. Solventless delignification of wood flour with $\mathrm{TiO}_{2} /$ poly(ethylene oxide) photocatalyst system. Journal of Polymers and the Environment. 2013;21(1):115-121. DOI: https:/doi.org/ 10.1007/s10924-012-0465-y

[133] Huber GW, Iborra S, Corma A. Synthesis of transportation fuels from biomass: Chemistry, catalysts, and engineering. Chemical Reviews. 2006;106(9):4044-4098. DOI: https:// doi.org/10.1021/cr068360d

[134] Ferdous D, Dalai AK, Bej SK, Thring RW. Pyrolysis of lignins: Experimental and kinetics studies. Energy \& Fuels. 2002;16(6):1405-1412. DOI: https://doi.org/10.1021/ef0200323

[135] Bridgwater AV. Principles and practice of biomass fast pyrolysis processes for liquids. Journal of Analytical and Applied Pyrolysis. 1999;51(1-2):3-22. DOI: https://doi.org/ 10.1016/S0165-2370(99)00005-4

[136] Gardner DJ, Schultz TP, McGinnis GD. The pyrolytic behavior of selected lignin preparations. Journal of Wood Chemistry and Technology. 2007;5(1):85-110. DOI: https://doi. org/10.1080/02773818508085182

[137] Piskorz J, Majerski P, Radlein D, Scott DS. Conversion of lignins to hydrocarbon fuels. Energy \& Fuels. 1989;3(6):723-726. DOI: https://doi.org/10.1021/ef00018a011

[138] Meier D, Ante R, Faix O. Catalytic hydropyrolysis of lignin: Influence of reaction conditions on the formation and composition of liquid products. Bioresource Technology. 1992;40(2):171-177. DOI: https://doi.org/10.1016/0960-8524(92)90205-C

[139] Thring RW, Chornet E, Overend RP. Thermolysis of glycol lignin in the presence of tetralin. Canadian Journal of Chemical Engineering. 1993;71(1):107-115. DOI: https:// doi.org/10.1002/cjce.5450710115

[140] Kudsy M, Kumazawa H, Sada E. Pyrolysis of kraft lignin in molten ZNCL 2 -KCL media with tetralin vapor addition. Canadian Journal of Chemical Engineering. 1995;73(3):411415. DOI: https://doi.org/10.1002/cjce.5450730319

[141] Song Q, Wang F, Cai J, et al. Lignin depolymerization (LDP) in alcohol over nickel-based catalysts via a fragmentation-hydrogenolysis process. Energy \& Environmental Science. 2013;6(3):994. DOI: https://doi.org/10.1039/c2ee23741e

[142] Connors WJ, Johanson LN, Sarkanen KV, Winslow P. Thermal degradation of kraft lignin in tetralin. Holzforschung. 1980;34(1):29-37. DOI: https://doi.org/10.1515/hfsg.1980.34.1.29 
[143] Anderson EM, Katahira R, Reed M, et al. Reductive catalytic fractionation of corn Stover lignin. ACS sustainable. Chemical Engineer. 2016;4(12):6940-6950. DOI: https://doi.org/ 10.1021/acssuschemeng.6b01858

[144] Pinto PCR, Costa CE, Rodrigues AE. Oxidation of lignin from Eucalyptus globulus pulping liquors to produce syringaldehyde and vanillin. Industrial and Engineering Chemistry Research. 2013;52(12):4421-4428. DOI: https://doi.org/10.1021/ie303349j

[145] Araújo JD, Grande CA, Rodrigues AE. Vanillin production from lignin oxidation in a batch reactor. Chemical Engineering Research and Design. 2010;88(8):1024-1032. DOI: https://doi.org/10.1016/j.cherd.2010.01.021

[146] Villar JC, Caperos A, García-Ochoa F. Oxidation of hardwood kraft-lignin to phenolic derivatives with oxygen as oxidant. Wood Science and Technology. 2001;35(3):245-255. DOI: https://doi.org/10.1007/s002260100089

[147] Bjørsvik H-R, Norman K. Fine chemicals from Lignosulfonates. 2. Synthesis of Veratric acid from Acetovanillon. Organic Process Research and Development. 1999;3(5):341-346. DOI: https://doi.org/10.1021/op9900030

[148] Humpert D, Ebrahimi M, Czermak P. Membrane Technology for the Recovery of lignin: A review. Membranes (Basel). 2016;6(3). DOI: https://doi.org/10.3390/membranes6030042 27608047

[149] Žabková M, da Silva EB, Rodrigues AE. Recovery of vanillin from lignin/vanillin mixture by using tubular ceramic ultrafiltration membranes. Journal of Membrane Science 2007;301(1-2):221-237. DOI: https://doi.org/10.1016/j.memsci.2007.06.025 
